

\begin{abstract}
This paper analyses the performance of the Central Bank of Kenya (CBK) in delivering on its mandate since the organisation gained formal independence in the early-1990s. It utilises a political settlements approach, tracking how the distribution of power has shaped CBK's effectiveness over time. The paper finds that Kenya's political settlement has constrained CBK's performance in certain respects, particularly with regards to financial sector supervision, where the organisation must operate within a tight set of political constraints because of the sector's importance in enabling vital patronage networks and generating political financing for elections. This has often incentivised CBK governors to undertake incremental reforms that balance developmental and political interests; governors who have not been willing to compromise in this way have undermined the organisation's independence and autonomy by provoking a backlash. The paper also finds that Kenya's competitive clientelist political settlement has caused difficulties for CBK in undertaking its price stability mandate. This is particularly the case during election periods, when the organisation faces pressure to adopt a looser stance. Nonetheless, despite these pressures, the paper finds that $\mathrm{CBK}$ has, overall, been effective in delivering on its core mandate throughout the period under analysis, to the extent that it can be labelled a long-standing 'pocket of effectiveness'. This is because three other sets of factors have played a kind of countervailing role, by keeping CBK relatively insulated from the most corrosive aspects of Kenya's competitive clientelism. These are: transnational factors; ideas and ideology; and organisational-level factors, including CBK's leadership and its formal and informal sources of autonomy.
\end{abstract}

Keywords: pocket of effectiveness, political settlement, Africa, Kenya, Central Bank

Tyce, M. (2020) The politics of central banking in Kenya: Balancing political and developmental interests? Pockets of Effectiveness Working Paper No. 7. Manchester, UK: The University of Manchester. Available at www.effective-states.org

This document is an output from a project funded by UK Aid from the UK government for the benefit of developing countries. However, the views expressed and information contained in it are not necessarily those of, or endorsed by the UK government, which can accept no responsibility for such views or information or for any reliance placed on them. 


\section{Introduction}

This paper analyses the Central Bank of Kenya's (CBK) performance in delivering on its mandate since the organisation gained formal independence in the early 1990s. CBK was selected as a case study for research because a preliminary expert survey conducted by the researcher had identified it as a potential example of 'pocket of effectiveness' (POE) within the Kenyan context, with 54 percent of participants identifying it as a highly effective public sector organisation. ${ }^{1}$ CBK received more than twice the number of nominations than the Kenya Revenue Authority (KRA) or Auditor General's Office, the second- and third-highest ranked public sector organisations within the survey, received. ${ }^{2}$ What is more, participants generally identified it as a long-standing high performer, having performed consistently since the 1990s. Intriguingly, CBK seemingly managed this despite frequent turnover of ruling factions related to Kenya's competitive clientelist political settlement, which theory suggests will tend to undermine the coherency and farsightedness of bureaucratic decision-making (Khan 2010). All of this makes it an interesting case study to investigate as part of ESID's comparative research into the politics of POEs and state capacity in sub-Saharan Africa.

This paper seeks to identify the causal factors that have shaped CBK's performance over time. The principal variable to be tracked is the political settlement, which Khan (ibid.:4) defines as 'a combination of power and institutions that is mutually-compatible and sustainable in terms of economic and political viability'. For Khan, different political settlements are distinguished by the underlying distribution of power. In countries where power is horizontally and vertically dispersed, as in Kenya, the political settlement is labelled as competitive clientelist. For Khan, these settings are often unconducive to high levels of state capacity or bureaucratic functioning, since elites are often preoccupied with ensuring their political survival, given the strength of excluded factions. The strength of lower-level actors within the ruling coalition, meanwhile, means that they also lack enforcement capacities. However, CBK's supposedly consistent performance since the 1990s does not immediately conform to these hypotheses, suggesting that other factors may have been at play. Referring to other ESID research, these might include ideational or transnational factors, neither of which are given much explanatory power within Khan's rationalinstitutionalist and methodologically nationalist framework (Hickey et al. 2015). The significance of these factors will therefore be tested. So, too, will organisational-level factors that Roll (2014) and others (e.g. Grindle 2012) have identified in previous research on

\footnotetext{
${ }^{1}$ Roll (2014:24) defines a POE as 'a public organisation which provides public services relatively effectively despite operating in an environment in which effective public service delivery is the exception rather than the norm'. Roll also argues that organisations need to maintain this status over a period of at least five years to be labelled as a POE. This paper uses Roll's definition and criteria.

${ }^{2}$ KRA was nominated by 19 percent of participants, while the Auditor General's Office was nominated by 15 percent. In total, 26 respondents - who were selected because they were deemed to possess an intimate and broad-based knowledge of Kenya's public sector - completed the survey. To be sure, this is a small sample size, and the responses that were given will have been influenced by the particular moment in time when the survey was administered. This was during February and March 2019, when perceptions of public-sector performance in Kenya were at a particularly low ebb because of media reporting on various high-profile corruption scandals. Nonetheless, the researcher believes that the responses gave useful insights into public-sector performance in Kenya, specifically by identifying relatively high performers like CBK that could then be investigated through in-depth primary research. Overall, the researcher utilised the same methodology for conducting the survey as that which has been outlined by Hickey (2019) in his concept paper for the project.
} 
POEs. These include the strength and embeddedness of an organisation's leadership, as well as its internal culture and autonomy. ${ }^{3}$

To assess the explanatory power of these factors, the paper moves through a series of stages. First, it draws on statistical data to offer a quantitative assessment of CBK's performance across its two core mandated tasks of price and financial sector stability since the early 1990s. In so doing, the paper identifies three broad periods in CBK's post-reform trajectory. The drivers of these periods are then explored qualitatively in the empirical sections of the paper, using available secondary literature and primary data generated through key informant interviews. ${ }^{4}$ Finally, an analytical section brings these findings together in an attempt to identify the key causal factors that have shaped CBK's performance over time.

\section{Central Bank of Kenya's performance}

The Central Bank of Kenya Act was revised in 1996, formalising CBK's operational independence in terms of conducting monetary policy - the overriding focus of which was to be on achieving price stability - while also giving it a clear mandate in promoting financial sector stability, as reflected in Kenya's rise on the Central Bank Independence (CBI) index that year (Figure 1). This section, then, draws on widely recognised statistical indicators to offer a visual representation of CBK's performance in meeting these two tasks - price and financial sector stability - since the early 1990s. The aim is to identify broad performance periods for $\mathrm{CBK}$, the drivers of which can then be explored qualitatively.

Starting with CBK's monetary policy functions, the most obvious indicator for capturing performance is annual inflation. This is presented in Figure 2, from which one can discern three broad periods. The first of these - seemingly a period of high performance, particularly when one considers the height from which inflation rates dropped - stretches from 1993 to 2002, when there was a 'remarkable' downward trend from 46 percent in 1993 to 2.2 percent by 2002 (Rotich et al. 2007:7). Inflation then 'started drifting upwards' again between 2003 and 2012, with 'marked increases' in 2008 and 2011 (Adam et al. 2010). That said, rates always remained within manageable levels, so it should be stressed that this was not a period of poor performance per se - just one of slightly less stability and generally higher inflation (Were and Tiriongo 2013). Finally, Kenya's third - and ongoing - period of performance began in 2013 , characterised by low and stable inflation throughout, save for a small blip in 2017.

\footnotetext{
${ }^{3}$ This conceptual framework has been detailed in a concept paper by Hickey (2019). All five country teams working on the project, researching POEs across Kenya, Ghana, Rwanda, Uganda and Zambia, have adopted the same conceptual approach.

${ }^{4}$ The researcher interviewed 43 key informants, who either had a knowledge of CBK and the financial sector or of Kenya's political economy more broadly. These included: current and former CBK officials; officials working at other state organisations that regularly interact with CBK; representatives of private and public banks that are both foreign- and locally owned; journalists; financial sector consultants; and political analysts. The overall methodology that the researcher used was the same as that which has been used by the four other country teams within the project. This methodology has been outlined in detail by Hickey (2019).
} 
Figure 1. CBI ranking, 1992-2010

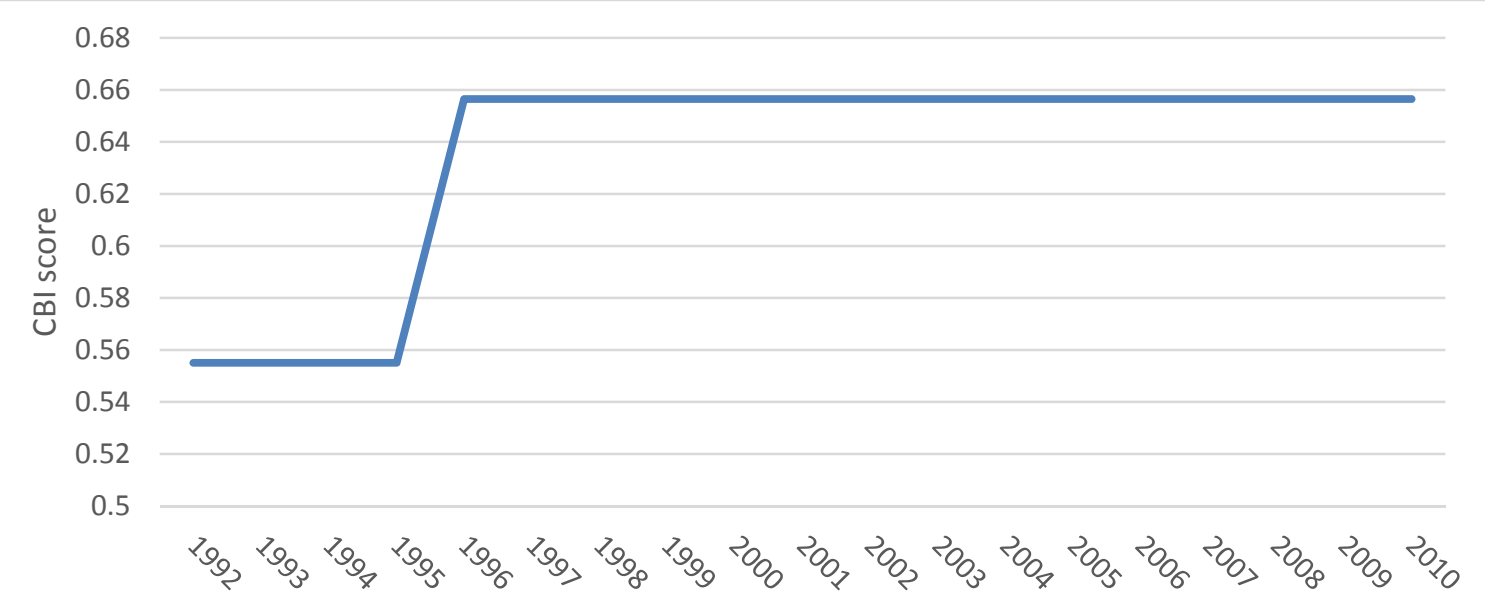

Source: Garriga (2016).

Figure 2. Inflation rates, 1992-2019

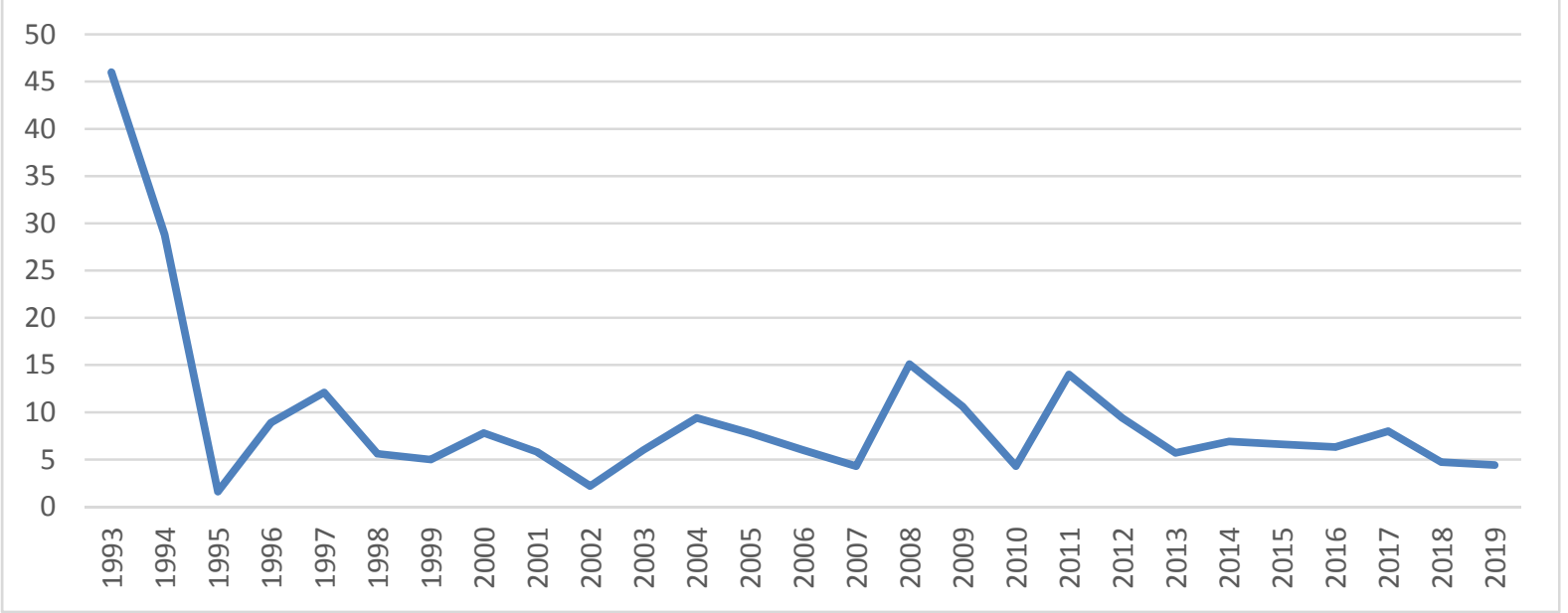

Source: $\underline{\text { https://www.imf.org/external/datamapper/datasets }}$

Intriguingly, indicators for financial stability reveal a similar set of periods, though the headline outcomes - in crude terms - contrast with those for inflation. Between 1993 and 2002, when CBK was achieving low and stable inflation rates, outcomes with regards to financial sector stability were more erratic. Kenya's Financial Development Index (FDI) metric, which offers a composite score of the depth, access and stability of a country's financial markets and institutions, improved between 1993 and 1996, but then declined thereafter, finishing at similar levels to where they had begun (Figure 3). A similar pattern is observed in ratios of non-performing loans (NPLs), a widely used indicator for assessing financial sector stability. Figure 4 shows a pronounced decline between 1993 and 1995, but then an equally dramatic resurgence thereafter, peaking in 2001 with a ratio of 40 percent that was even higher than where it had started. Figure 5, meanwhile, reveals that an unprecedented 28 bank and non-bank financial institution (NBFI) closures occurred between 1993 and 2001. 
Figure 3. FDI ranking, 1992-2016

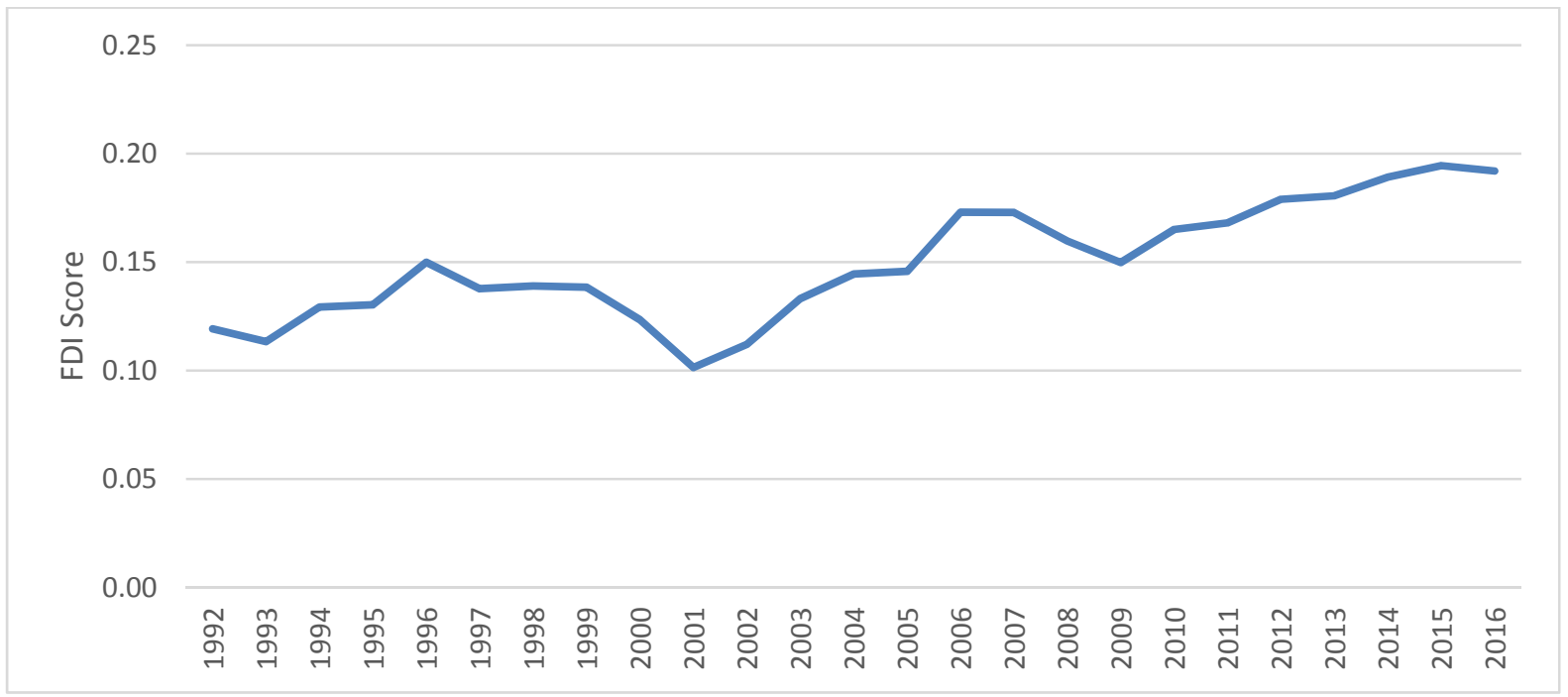

Source: https://www.imf.org/external/datamapper/datasets

Figure 4. NPLs, 1992-2018

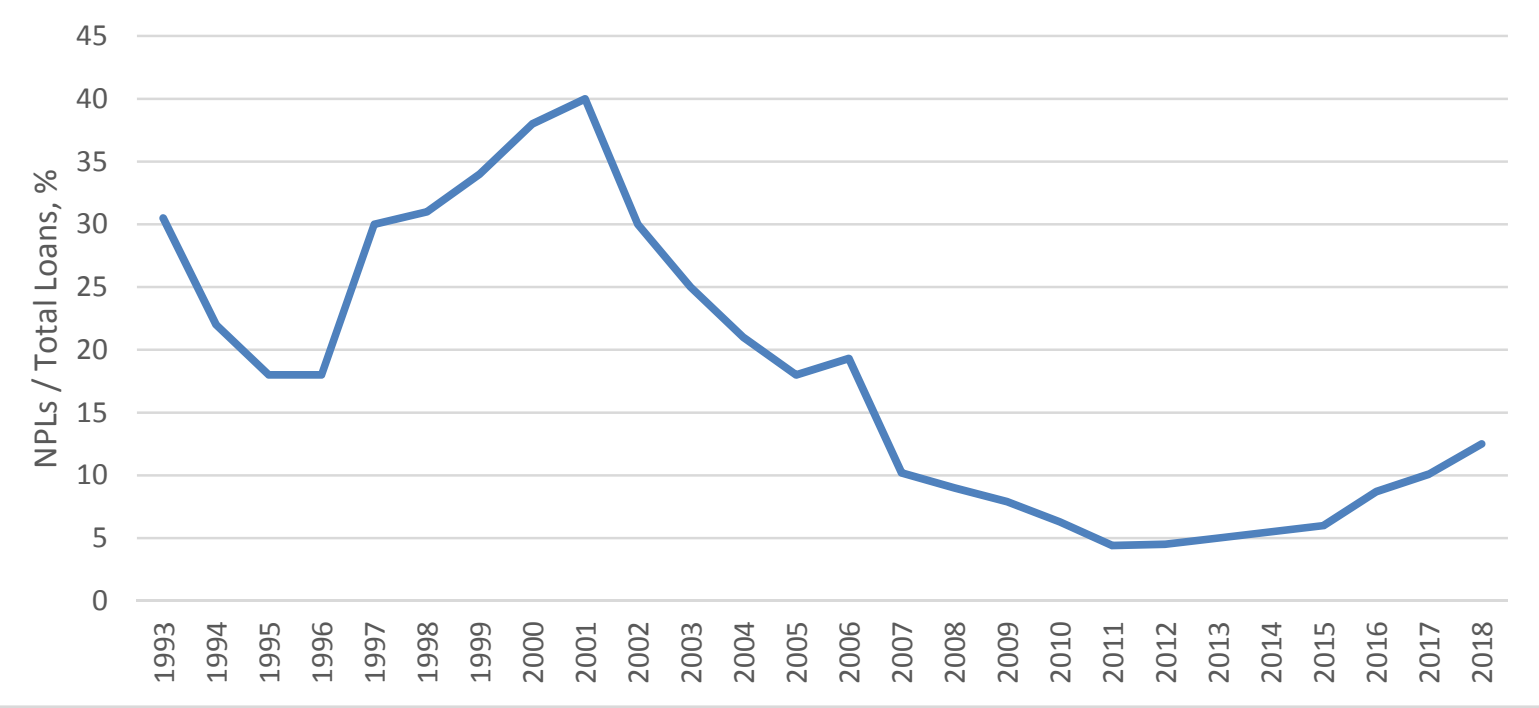

Source: Data for 1993-2006 comes from Upadhyaya (2011); thereafter, it comes from the World Bank (https://data.worldbank.org). 
Figure 5. Bank closures, 1992-2018

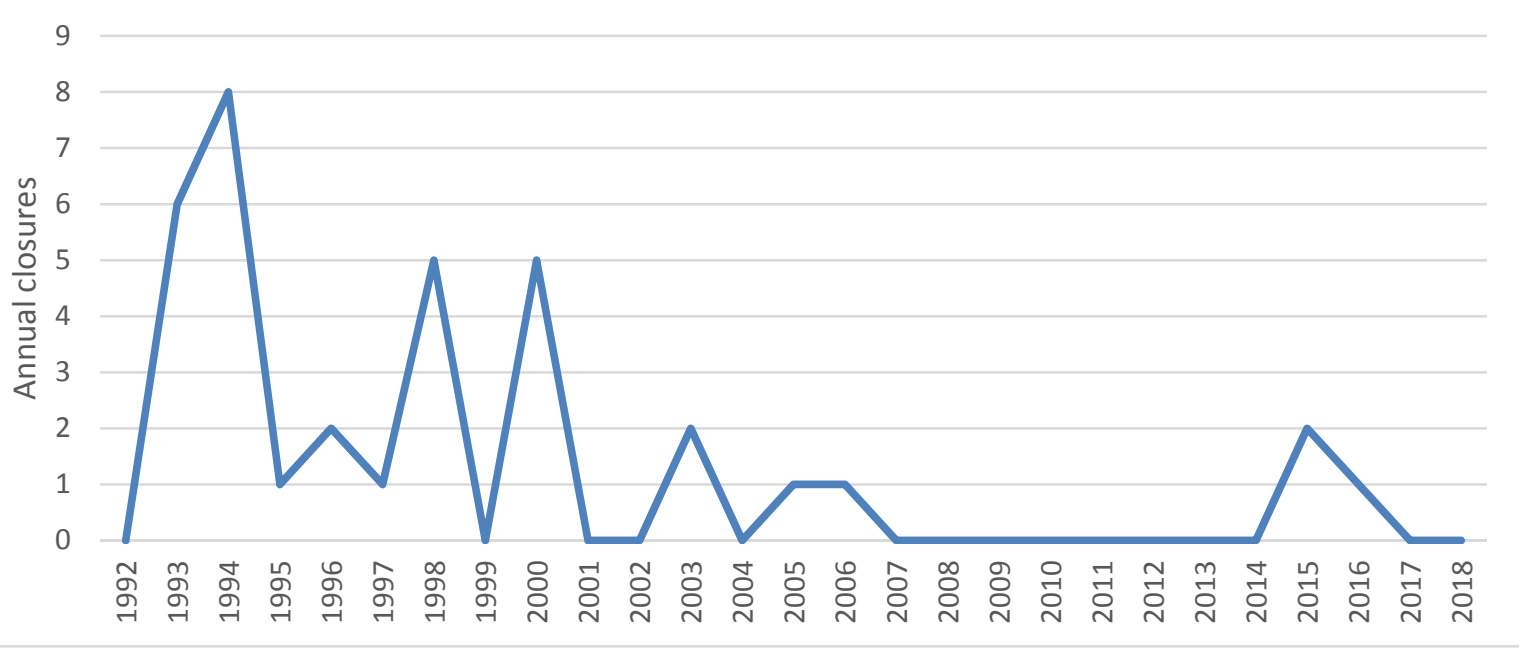

Source: Author's calculations, based on Brownbridge (1998), Upadhyaya (2011) and various newspaper/online sources.

Similarly, where the 2002-2012 period saw slightly higher inflationary pressures than before, the situation was the inverse with financial sector stability, as all indicators show marked improvements. Kenya's FDI score increased consistently, save for a lull between 2008 and 2009. The picture of improved outcomes seems even clearer when one looks at NPLs, which plunged from 40 percent in 2001 to 5 percent in 2012. In terms of bank closures, there were four between 2002 and 2006, then none for the remainder of the period. For these years, one can also refer to indicators that are tracked by the IMF's Financial Soundness Indicators database, which begins from the mid-2000s. These include capital adequacy and liquidity ratios (Figures 6 and 7), which together paint a picture of the sector's solvency and liquidity, as well as returns on assets, which offers a snapshot of the sector's profitability (Figure 8). These three indicators all show pronounced improvements between 2002 and 2012.

Figure 6. Capital adequacy ratio, 2004-2018

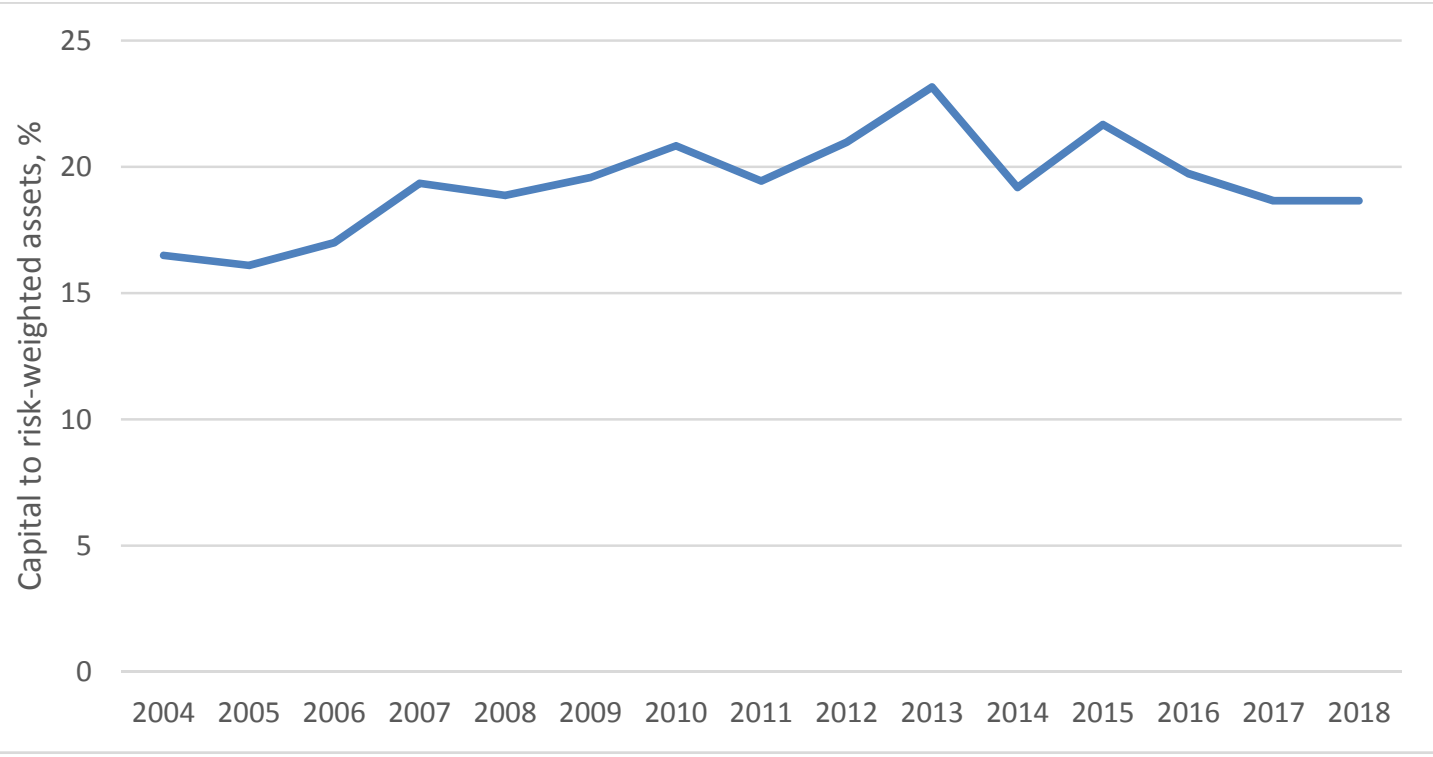

Source: $\underline{\text { http://data.imf.org/FSI. }}$ 
Figure 7. Liquidity ratio, 2006-2018

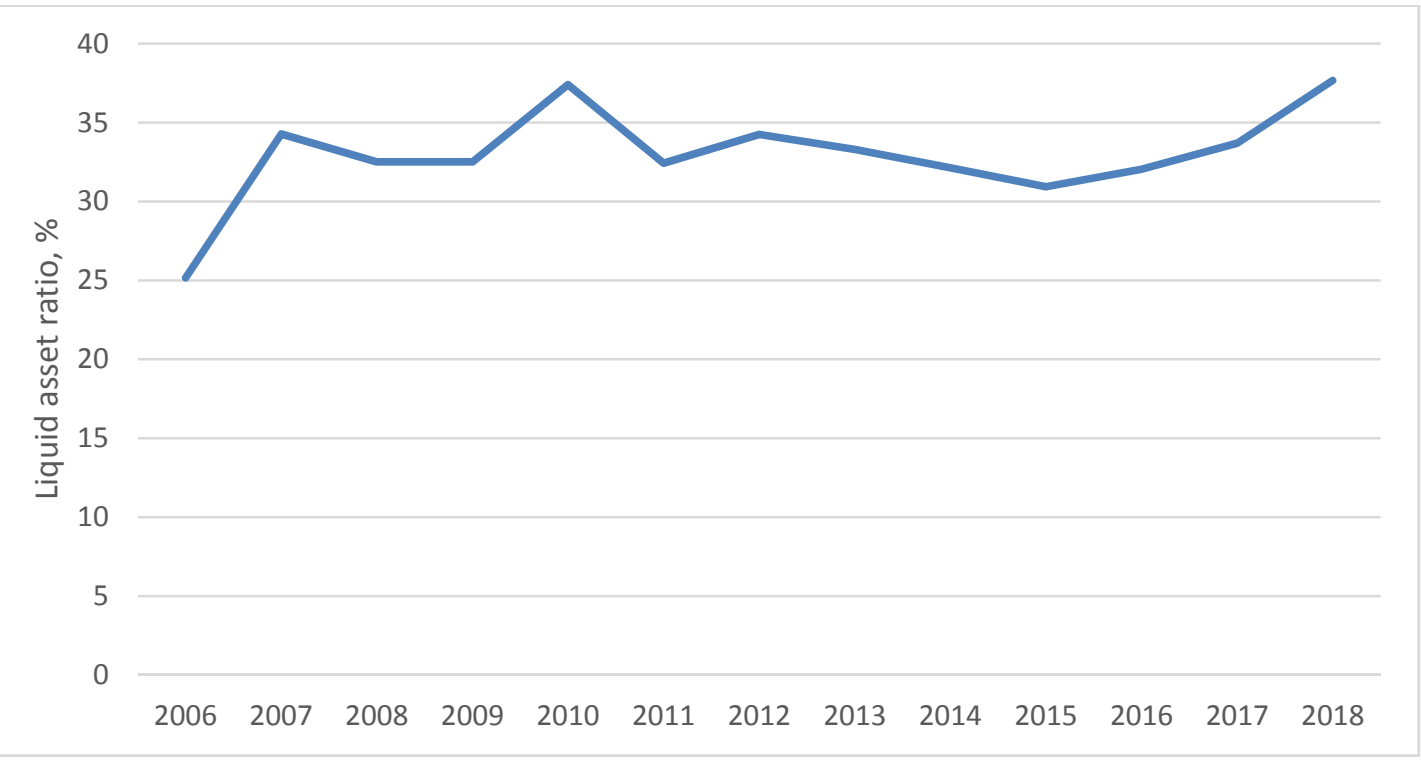

Source: Ibid.

Figure 8. Return on assets, 2006-2018

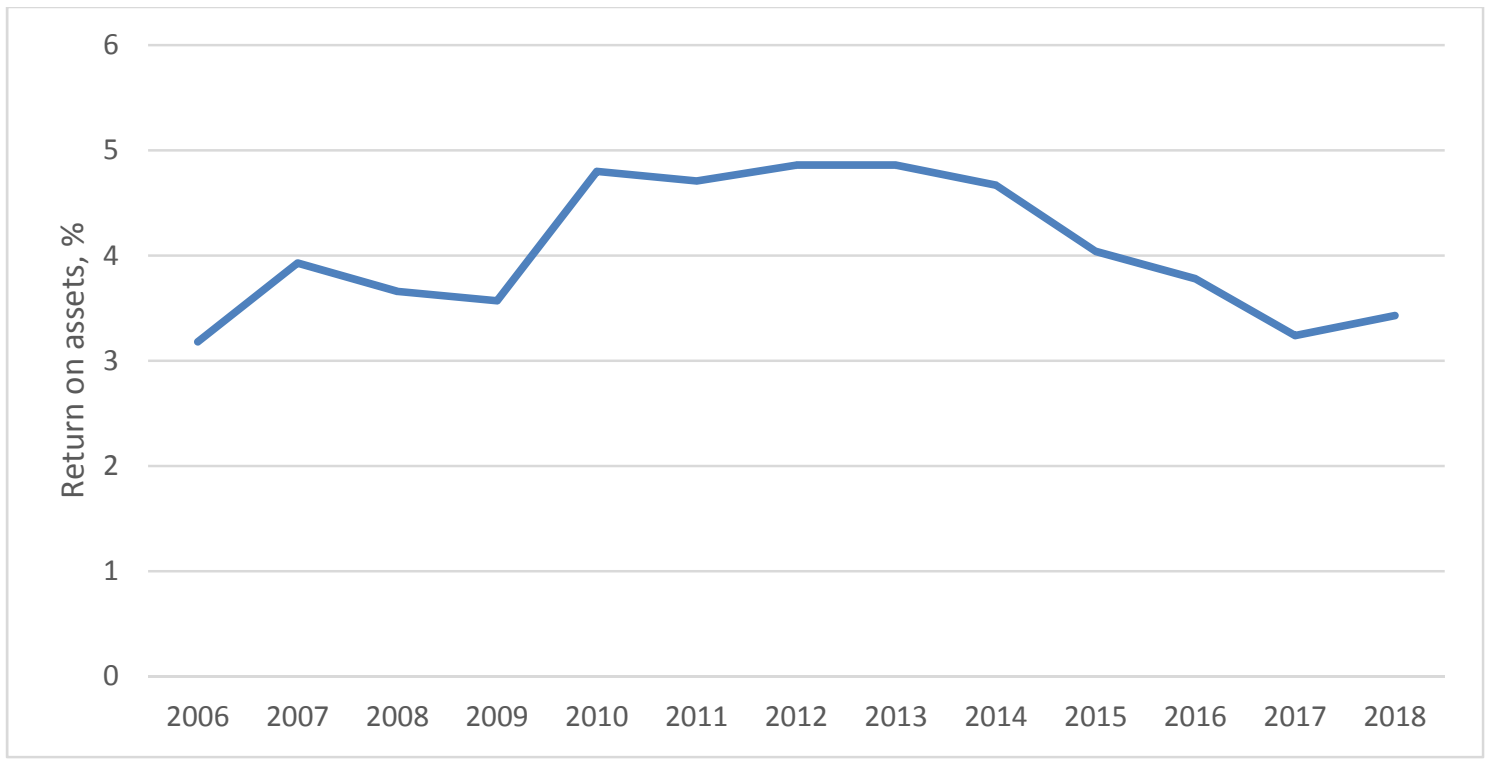

Source: Ibid.

Finally, where impressive inflationary outcomes were identified from 2013, Figures 3 to 8 suggest that performance has been less impressive in terms of financial sector stability. FDI data only stretches until 2016, but one can observe a small dip in Kenya's ranking from 2015. This could easily be dismissed if seen in isolation, given that Kenya's FDI score has rarely moved in a straight line and subsequent data is not available to confirm whether this was a one-off. However, Figures 4 and 5 suggest that there may, indeed, be a pattern of reduced financial sector stability, as there has also been a rise in NPLs in addition to three bank closures, after none in the previous eight years. Figures 6,7 and 8 also reveal worsening outcomes in Kenya's financial soundness indicators from around 2013, though at least with respect to liquidity ratios they have rebounded since 2015 . That said, it should be 
noted that, despite the declining outcomes, Kenya's capital adequacy and liquidity ratios have still remained well above the statutory minimum levels of 14.5 percent and 20 percent, respectively.

Taken together, these figures identify three performance periods, though curiously the headline outcomes across CBK's two core tasks have generally moved in opposite directions. These periods are 1993-2002, 2003-2012 and 2013-present. Importantly, these periods map onto periods identified by informants when discussing CBK's performance over time. These periods, then, will be used to structure the paper's empirical sections, whereby qualitative data generated through key informant interviews will be analysed to identify the drivers of these performance patterns. First, though, the paper offers an historical summary of central banking in Kenya, from the country's independence in 1963 until its reform era in 1993. This analysis will also be linked to the evolving nature of Kenya's political settlement.

\section{CBK in historical and political perspective}

CBK was established in 1966, three years after Kenya gained independence. This followed the dissolution of the East African Currency Board (EACB), which had been inherited from the colonial period, but quickly faltered as Uganda, Tanzania and Kenya abandoned their common currency and introduced separate exchange controls (Nyorekwa and Odhiambo 2014). EACB's former head was chosen to lead CBK during a transition period but, in 1967 , Duncan Ndegwa, a UK-educated economist, was appointed as governor. Ndegwa remained in position until 1982, making him the longest-serving governor in Kenya's history.

This stability in CBK's leadership resulted from stability within Kenya's political settlement. Between 1963 and 1982, Kenya had a weak dominant settlement constructed by founding President Jomo Kenyatta, who managed to assemble a relatively inclusive ruling coalition albeit a highly fragmented one that was dominated by his own Kikuyu ethnic group - through a combination of his legitimacy as an independence leader and his access to state patronage (Nyong'o 1989). This weak dominant party was then inherited by Vice President Daniel arap Moi in 1978, following Kenyatta's death. Moi initially tried to retain the extensive patron-client networks that Kenyatta had built, keeping many of his trusted lieutenants in place. This was primarily to signal continuity to Kikuyus, who had fought over whether to allow Moi, a member of the smaller Kalenjin community, to inherit the presidency as Kenyatta had decreed.

CBK's mandate mirrored most central banks at this time, focused on ensuring an efficient monetary system and serving as the government's banker, with little power to license and regulate banks. In terms of monetary tools, CBK had four main instruments, all of which were direct controls, namely: minimum reserve ratios; private sector credit ceilings; managed interest rates; and sectoral credit allocation (Gichuki et al. 2012). Riding a wave of high commodity prices and inward investment - the latter of which was due partly to its ultralow, almost negative, interest rate policy - CBK generally succeeded in keeping inflation between 0 percent and 3 percent throughout the first decade of independence (Killick and Mwega 1990). 
CBK's success in ensuring low inflation was also a function of its cooperation with the Treasury, another organisation that enjoyed stability in its (Kikuyu) leadership. While Kikuyu dominance over the macroeconomic technocracy certainly had pernicious effects, ensuring a disproportionate flow of credit, fiscal incentives and support to firms and sectors that were dominated by them, it did assist with macroeconomic stability and performance, given the coordination that developed between the Treasury and CBK (O'Brien and Ryan 2001). Another important point is that, while Kenyatta favoured his own community, he also recognised the importance of appointing credible candidates - and, critically, had sufficient political space to do so. Kibaki and Ndegwa were UK-educated economists who used their clout and relational linkages to maintain a degree of autonomy within their organisations, winning praise from the World Bank (1975:5) for 'praiseworthy' fiscal and monetary policies.

However, a shift in Kenya's settlement in 1982 triggered a decline in CBK's performance. During the first years of his presidency, which began in 1978, Moi struggled holding the weak dominant party together, as a crash in commodity prices - particularly for tea and coffee, Kenya's principal exports - reduced his ability to co-opt rivals. The result was an attempted coup in 1982, which prompted Moi to expunge implicated groups like the Kikuyu from his coalition (Chege 1994). Instead, Moi leant heavily on Kalenjin co-ethnics and a patchwork alliance of previously peripheral pastoralist groups. This shifted Kenya's settlement towards vulnerable authoritarianism, as excluded factions grew in strength and Moi adopted authoritarian tactics to undermine their holding power.

Kikuyus were removed from leadership positions across the bureaucracy (O'Brien and Ryan 2001). These included long-standing CBK governor Ndegwa and Finance Minister Kibaki. Moi replaced them with George Saitoti, a Maasai and Eric Kotut, a Kalenjin, respectively, exemplifying the narrowing base of his coalition. Having secured control of the macroeconomic technocracy, Moi then began restructuring the financial sector. $\mathrm{He}$ embarked on 'a systematic campaign to strangle Kikuyu-owned banks' that had been licensed during the previous period, re-directing parastatal deposits towards new Kalenjinlinked banks (Brownbridge and Harvey 1998). ${ }^{5}$ Having consolidated control over the financial sector, the third stage in Moi's financial repression strategy was then revoking credit to Kikuyu-owned firms generally, triggering a wave of collapses across sectors in which they were predominant, notably manufacturing, trading, tea and coffee (Arriola 2013).

Moi's campaign to stymie Kikuyu economic power was conducted irrespective of the costs, which only compounded the difficulties presented by the commodity price crashes. Inflation rates accelerated, and exchange rates depreciated, the combination of which drove up the deficit throughout the 1980s, while CBK's reserves dwindled to well below target levels (Ngugi and Kabubo 1998). This forced the government into domestic borrowing, which only exacerbated inflationary dynamics further, and into securing high-conditionality credits from the IMF, which became increasingly influential. The IMF's growing presence was felt particularly in its demands for reform, both for economy-wide reforms around liberalisation and for financial sector reforms to be spearheaded by CBK (Ndung'u and Ngugi 1999).

\footnotetext{
${ }^{5}$ Interview, journalist, Nairobi, 7 December 2016.
} 
Formally, Kenya bowed to these demands from the mid-1980s, when Moi's government arranged a string of structural adjustment loans and overhauled the CBK Act according to donor prescriptions, giving CBK powers to license, supervise and regulate banks and to 'issue wide-ranging penalty-backed directions to institutions that fail to adhere to the act' (CBK 1989:8). These reforms were, however, designed more as a signalling mechanism to the international community than a serious statement of intent. This is because their genuine enforcement would have curtailed the ability of Moi's coalition to generate political financing just as Kenya's political settlement was undergoing another shift.

The emergence of competitive clientelism could be traced to 1992, when Moi bowed to democratisation pressures by scheduling multi-party elections. However, this would miss the observation that Moi surreptitiously started laying the groundwork for these elections from around 1990, all the while maintaining publicly that he was countenancing no such thing. Nowhere is this reality clearer than in the financial sector, where CBK and Treasury devised ways to finance the impending elections 'regardless of the costs' (Throup and Hornsby 1998:583). CBK licensed 'political banks' that embarked upon breathtaking insider lending, taking the total number of banks from 24 in 1990 to 40 in 1993 (Upadhyaya 2011). CBK also ordered state-owned banks, like National Bank of Kenya and Kenya Commercial Bank, to expand their branch networks, providing Moi with conduits to disperse funds to increasingly influential low-level actors within the constituencies (Arriola 2013).

The Treasury, CBK and various political 'banks' also orchestrated the Goldenberg scandal, which drained Kenya's economy of up to 16 percent of its GDP between 1990 and 1993 (Warutere 2005). Goldenberg was designed to finance the 1992 elections, and in that sense it succeeded. Moi won with around a third of the votes by using Goldenberg cash to finance competing presidential candidates, pay ethnic militia to suppress opposition supporters in vote-rich parts of the country, and establish youth groups which became little more than 'vote-buying machines' (Kajwanja 2009:369). However, it was also the exposal of Goldenberg in 1993, along with the destruction that it unleashed on the economy, that finally propelled Kenya, and specifically CBK, into its neoliberal reform era, as the following sections demonstrate.

\section{The 'clean-up phase', 1993-2002}

Details of Goldenberg were leaked after the 1992 elections, prompting donors to make a continuation of their support conditional on reform. Additionally, there was pressure from powerful domestic capitalist groups for reform (Dafe 2019). Notably, this came from Kenyan Asian capitalists who had struck close relations with Moi's inner circle during the 1980s by fronting their businesses and funding their political expenditure (Throup and Hornsby 1998). They were complaining that their businesses, many of which were export-focused, were suffering from worsening inflation and exchange rates. So, too, were powerful associations representing Kenya's horticulture sector - which had grown rapidly since the late 1970s, attracting investment from senior political elites - demanding reform. ${ }^{6}$ Intriguingly, pressure also came from elements of the Kikuyu commercial class, with whom Moi, demonstrating the vagaries of competitive clientelism, was once again cosying up, in order to stem the

\footnotetext{
${ }^{6}$ Interview, director of horticultural business association, Nairobi, 27 April 2017.
} 
opposition's political financing (Kanyinga 1994). These businesspeople were seeking liberalisation to ensure that they could not be targeted again by the state following further changes in political headwinds, confirming Boone's (2005) claim that those who have suffered from financial repression are likeliest to push for market-opening reforms. It was, then, pressure from a range of actors that convinced Moi of the need for reform.

Knowing that reforms would not be credible under Kotut, Moi replaced him in 1993 with the relatively unknown Micah Cheserem, who was dubbed the 'The Cleaner' for 'covering Moi's tracks' and restoring Kenya's credibility. ${ }^{7}$ Cheserem had been a director of Unilever, utilising his training as an accountant to oversee its financial matters. While Cheserem was not an economist, he was 'an immensely competent accountant', the principles of which he brought to $\mathrm{CBK}^{8} \mathrm{He}$ was also 'connected to international networks', especially the IMF and World Bank. ${ }^{9}$ Such were Cheserem's external connections that many portray him as a candidate who was forced upon Kenya. However, this misses a key dimension of what made him attractive domestically as well. Cheserem was a Kalenjin and brother-in-law to Joshua Kulei, Moi's closest advisor, giving him 'access to State House'. ${ }^{10}$ For one official who served under him, it was these relational links, more than the qualifications, that made Cheserem the 'ideal candidate'. ${ }^{11}$ 'A governor', he explained, 'is there to deal with the politics and Cheserem did that well. He did not know much about economics, but he knew how to read the mood of politics and had the president's ear'. ${ }^{12}$ Importantly, Cheserem also knew how to mitigate his lack of technical knowledge by being 'a good listener'. ${ }^{13}$ In particular, he leant on his deputy, Thomas Kibua, an economist whose own appointment, within weeks of Cheserem's, struck a balance between the political and technical in CBK's leadership.

Cheserem and Kibua drove substantial reform, internally and externally. Internally, Cheserem's corporate accounting background meant that he was receptive to calls from donors to revise CBK's constitution. This resulted in the introduction of four-year term limits for governors, deputies and directors, as Cheserem felt that 'elastic terms did not create incentives for strong performance'. ${ }^{14}$ A rule whereby board meetings were only quorate when the Treasury's representative was present was also removed, as this had 'meant that if Treasury wanted to pressure CBK, then it just had to stay away'. ${ }^{15}$ Externally, Cheserem was a champion for liberalisation reforms, convinced by the case that was put to him by donors, who 'worked largely through him'. ${ }^{16}$ Cheserem played a key role in relaying their benefits to Moi's inner circle, helping to explain the speed with which Kenya's era of controls ended after his appointment, with removal of import licences and liberalisation of exchange rates occurring in late 1993 and exchange controls lifted the next year (Bandiera et al. 2008). In addition to agreeing with donors on the need for liberalisation, Cheserem was also

\footnotetext{
${ }^{7}$ Interview, business reporter, Nairobi, 5 May 2017.

${ }^{8}$ Interview, CBK manager, Nairobi, 29 April 2019.

${ }^{9}$ Interview, former CBK manager, Nairobi, 3/ April 2019.

${ }^{10}$ Interview, journalist, Nairobi, 28 April 2019.

${ }^{11}$ Interview, CBK official, Nairobi, 29 April 2019.

12 Ibid.

${ }^{13} \mathrm{lbid}$

${ }^{14}$ Interview, former CBK manager, Nairobi, 03 April 2019.

${ }^{15} \mathrm{lbid}$

${ }^{16}$ Interview, journalist, Nairobi, 28 April 2019.
} 
- partly on account of his lack of training in economics, which meant that he had few alternative ideas to draw upon, but also encouraged by his deputy - equally amenable to donor advice on conducting monetary policy within a liberalised environment, as the next section reveals.

\subsection{Monetary policy}

Section 2 found that monetary policy outcomes, at least with respect to price stability, were impressive between 1993 and 2002. Inflation declined from 46 percent in 1993 to 29 percent in 1994, then dropped into single figures for the rest of the period, save for a blip in 1997. Scholars generally explain these outcomes with reference to donor influence, as the imperative of resuming aid supposedly left the government with little option but to adopt a 'conventional' tight monetary stance that was being promoted across the continent (Bandiera et al. 2008; Adam et al. 2010). This was reflected in changes to the CBK Act in 1996, which narrowed CBK's monetary policy mandate around a 'primary objective' of price stability (Rotich et al. 2007; Nyorekwa and Odhiambo 2014:499). According to the revised Act, the Treasury would, in consultation with CBK, set annual inflation targets to achieve the desired level of stability; however, the target remained at a rigid 'below 5 percent' throughout the period (IMF 2015:20). This was the exact same target as that which was adopted by many other African countries at the time, which Goldsbrough et al. (2007) see as clear proof of donor pressure.

There was, however, also support for a tight monetary stance from domestic capitalists, whose businesses were hurting due to the economic shockwaves that Goldenberg unleashed (O'Brien and Ryan 2001; Dafe 2019). Goldenberg not only caused unprecedented inflation, but volatility in exchange and interest rates as CBK mopped up excess liquidity by issuing Treasury Bills (Kinyua 2001). As the previous sub-section explained, particularly affected groups included Kenyan Asian capitalists and investors in Kenya's horticultural sector, who were involved in exporting activities that required macroeconomic stability for continued expansion. ${ }^{17}$ Pressure from these capitalists was critical in pressuring CBK to deliver on its inflation mandate, especially since new investors in horticulture during the 1990s included President Moi and CBK's new governor, Cheserem. ${ }^{18}$ These commercial interests gave key policymakers a personal incentive to foster macroeconomic stability.

One should also not underplay the extent to which donor prescriptions aligned with the ideational persuasions of CBK's leadership. Cheserem may not have been an economist, but he was a firm believer in the advice that he received from donors, as they fitted with his own accounting principles. ${ }^{19}$ In his biography, Cheserem (2006:123) recalls that he 'readily agreed' with donors, for which 'some people in government accused me of being too close to the IMF'. So, too, was Cheserem's neo-classically trained deputy, Kibua, convinced of the merits of tight monetary policy, despite the resistance that it provoked from certain political

\footnotetext{
17 Interview, journalist, Nairobi, 21 November 2016.

18 Interview, director of horticultural business association, Nairobi, 27 April 2017.

${ }^{19}$ Interview, former CBK manager, Nairobi, 27 March 2019.
} 
quarters, where a looser stance was preferred. ${ }^{20}$ In particular, CBK drew fire for demanding that the government's overdraft facility be capped at 5 percent of its revenues from the last audited accounts, which was a 'relatively low' figure 'compared to regional peers' (IMF 2015:23). Cheserem moved to implement the cap in 1998, having become frustrated during the previous year (an election year), when he had been unable to prevent sizeable build-ups in the overdraft that had threatened to undo progress in promoting price stability (as seen earlier in Figure 2, with the inflation spike in 1997). To bring the overdraft back down, and to quell inflationary pressures, Cheserem convinced the Treasury to issue large numbers of Treasury bills and bonds in late 1997. This mopped up excess liquidity, but had knock-on effects in terms of driving up interest rates (CBK 1998). This was seemingly the lesser of two evils for CBK, given its primary mandate of price stability, but the whole episode motivated Cheserem to strictly implement the overdraft limit from 1998 onwards. ${ }^{21}$ This, then, perhaps helps to explain a particularly intriguing outcome between 2001 and 2002, whereby there was no escalation in inflation, despite Kenya moving towards a crunch election in which Moi was attempting to secure the presidency for his favoured successor, Uhuru Kenyatta.

Cheserem's preference for restrained monetary policy was such that his tenure apparently led to a hobbling of CBK's research department. ${ }^{22}$ The department's staffing and budget was slashed, partly because of Cheserem's conviction in the advice that he received from donors and his deputy, which meant that he saw 'little need for a research department that would investigate alternative policy approaches'. ${ }^{23}$ However, a former official recalled that it also derived from Cheserem's background, as he was 'a corporate person from the accounting profession, so he was not interested in research papers with lots of footnotes. He just wanted people to give him numbers'. ${ }^{24}$ As a result, while CBK certainly delivered on its monetary policy mandate during the 1990s, the process was 'not open'. ${ }^{25}$ An insider even described it as a 'one-man band'. ${ }^{26}$ 'Research was not feeding into policy decisions', he explained, 'and that should always be a concern for a Central Bank'. ${ }^{27}$ Some of CBK's core capacities, then, were seemingly undermined - or, at least, stunted - under Cheserem, despite the good headline outcomes.

\subsection{Supervision}

Where this period saw pronounced improvements in price stability, outcomes with regards to financial sector stability were more erratic. Section 2 found that there were improvements in Kenya's FDI ranking and NPL ratio between 1993 and 1996, but that this progress unravelled thereafter, leaving both indicators at roughly similar levels in 2002 as they had been in 1993. Meanwhile, there were numerous bank and NBFI closures throughout, totalling 28 between 1993 and 2002, with pronounced spikes in 1993-94 and 1998.

\footnotetext{
20 Ibid.

21 Ibid.

22 Interview, economic analyst, Nairobi, 6 March 2019.

${ }^{23}$ Interview, former CBK manager, Nairobi, 27 March 2019.

${ }^{24}$ Interview, former CBK manager, Nairobi, 21 March 2019.

25 Ibid.

${ }^{26}$ Interview, CBK director, Nairobi, 6 April 2019.

${ }^{27}$ Ibid.
} 
The initial improved outcomes are often attributed to the introduction of new legislation that mirrored international best practice. In 1993, CBK adopted a universal banking policy and eliminated regulatory advantages enjoyed by NBFIs; in 1994, it then adopted aspects of Basel I, notably around single borrower limits (Brownbridge 1998). Further Basel-inspired reforms followed in 1998, which introduced detailed guidelines around provisioning, and again in 2000, when minimum capital requirements were increased. Scholars argue that these reforms incentivised better corporate governance, restricting the appetite of banks for insider lending and acquiring NPLs (Adam et al. 2010; Mwega 2016).

A deeper examination suggests that Moi's government often unveiled such legislation as a signalling device to the international community, as doing so gave Cheserem the cover that he needed to perform a delicate 'juggling act' behind-the-scenes. ${ }^{28}$ On the one hand, Cheserem had to restore confidence by fostering sufficient stability, but, on the other, he had to give Moi's inner circle enough leeway to continue generating political financing by not infringing on the patronage networks which flowed through the sector. Working closely with State House, Cheserem sought to strike this balance by closing and restructuring enough of the political banks - particularly those whose sole purpose had been channelling Goldenberg cash - to appease outsiders, particularly donors, but leaving enough banks untouched so as not to threaten Moi's chances of re-election in 1997. These included Moi's own Transnational Bank, which was, according to a then CBK manager, 'off-limits' to examiners. ${ }^{29}$

These insights help to explain the improved outcomes until 1996, as Cheserem fostered a degree of stability within the sector after it had 'spiralled out of control' during Kenya's initial transition to competitive clientelism. ${ }^{30}$ As to why there was a reversal in fortunes thereafter, informants linked this to the 1997 elections, which caused competitive clientelist dynamics to ramp up once more. The remaining political banks upped their insider lending again, explaining part of the rise in NPLs. Even more important in this trend, however, were state banks like National Bank of Kenya, Consolidated Bank of Kenya and Kenya Commercial Bank, which became the new accumulators of bad debt after 1993, as Moi realised that their activities could be more easily concealed. Their NPL ratios rose to 84 percent, 72 percent and 42 percent, respectively, by 1998, while public banks as a whole accounted for twothirds of NPLs that year, a much higher proportion than in 1992 (Arriola 2013). Thus, while Kenya's NPL ratio returned to roughly where it had been, this conceals an important shift in distribution, since NPLs became concentrated in state-owned banks. In turn, the increasing importance of state banks to Moi's survival helps to explain why Cheserem, ever mindful of the politics of his position, resisted donor demands to privatise them, a stance that might initially seem counter-intuitive, given how enthusiastically he championed other liberalisation reforms. ${ }^{31}$

\footnotetext{
${ }^{28}$ Interview, journalist, Nairobi, 28 April 2019.

${ }^{29}$ Interview, former CBK manager, Nairobi, 3 April 2019.

${ }^{30} \mathrm{lbid}$

${ }^{31}$ Interview, business reporter, Nairobi, 5 May 2017.
} 
Following the 1997 elections, Cheserem again entered 'clean-up' mode. ${ }^{32} \mathrm{He}$ embarked on another round of closures in 1998, after banks had served their purpose in getting Moi reelected, as well as in 2000-01, when it became clear that Moi would be unable to change the constitution to stand for a third term and that Moi's favoured successor, Uhuru Kenyatta, was unlikely to defeat the opposition leader, Mwai Kibaki. Cheserem sought to 'cover Moi's tracks', by closing down banks and tying up any loose ends on political financing schemes that could be traced back to him ahead of the increasingly inevitable handover of power. ${ }^{33}$ This, then, perhaps explains why financial sector indicators showed signs of recovery in 2001-02.

Cheserem needed a deft political touch to bring even a modicum of stability to Kenya's financial sector. The overriding priorities of generating political financing within a context of competitive clientelism prevented anything other than incremental reform. Indeed, these political sensitivities meant that all key decisions relating to supervision were made by Cheserem and a small group of advisors. ${ }^{34}$ Many were drafted from outside CBK, despite them having no training or knowledge of CAMEL principles, which were the guiding philosophy for supervision. This, according to one informant, 'sidelined' existing examiners, who had received training from the World Bank since the mid-1980s, but were thereafter moved to other departments ${ }_{2}$ or given menial work. ${ }^{35}$ This drew fire from the IMF, which:

'told us off, because you need more than ten years of training to be a good examiner, to know what to look for ... They kept telling us to strengthen supervision, to direct more resources to it, to bring back the examiners, so I never understand how people have this impression that the department improved under Cheserem ... There was no real effort to build its capacity. 36

Seemingly corroborating these claims, a World Bank survey conducted in 2002 found that Kenya had just one examiner with over ten years' experience (World Bank 2003).

\subsection{Overall performance}

These findings help to explain the divergence in CBK's performance across its core mandated tasks between 1993 and 2002. Monetary policy performance, at least in terms of price stability, was strong because the interests of domestic and external actors aligned around macroeconomic stability and low inflation. CBK's performance in ensuring financial stability, by contrast, was more variable, and closely tied to electoral cycles, because of the sector's role in greasing Moi's patronage networks. Nonetheless, given the political confines within which CBK had to operate when undertaking this side of its mandate, as well as the sheer size of the task that faced Cheserem when he entered office in 1993, this paper argues that CBK's performance was still reasonably strong here as well. That said, the paper refrains from labelling CBK as a fully-fledged POE during this period, as it did not demonstrate important criteria that Roll (2014) associates with being one. In particular, there

\footnotetext{
${ }^{32}$ Ibid.

${ }^{33}$ Ibid.

${ }^{34}$ Interview, former CBK official, Nairobi, 2 April 2019.

35 Interview, former CBK manager, Nairobi, 21 March 2019.

${ }^{36}$ Ibid.
} 
are doubts as to whether it possessed the organisational culture that might be expected of a POE, certainly a sustainable one, as officials outside of Cheserem's clique were not trusted to do their work or given much responsibility. Cheserem took a personalised approach to CBK's monetary and regulatory functions, partly because of the political sensitivities of his job, but also because of his own personality and management traits. This approach proved successful in meeting the bank's mandated objectives, but resulted in the hollowing out of critical departments like research and supervision, in turn undermining - or at least restraining the development of - core organisational capacities.

\section{Broadening the technocratic base, 2003-2012}

This situation was somewhat reversed during between 2002 and 2013, as increased emphasis was placed on building CBK's institutional faculties. This shift, according to informants, was related to Kibaki's victory in the 2002 elections, since Kibaki was a trained economist with a vision for the economy, one that he strove to implement despite counterveiling incentives across both terms. During his first, Kibaki led a fragmented National Rainbow Coalition (NARC) that had only united out of a shared desire to unseat Moi, and which quickly collapsed once in power. His second was spent managing an even more fragmented (and bloated) unity government that was formed after the 2007-08 election violence, one that comprised all major factions and had an expanded cabinet to accommodate them (ODI 2014).

Kibaki's presidency was therefore undermined by power struggles across the bureaucracy, as competing ethnic factions competed for rents and supremacy. The one area that somewhat escaped these dynamics, however, was the macroeconomic technocracy, where Kibaki used up much of his political capital in trying to insulate it because of its importance to his vision. Kibaki appointed technocrats across the Treasury, CBK and KRA, all of whom were 'given space to work'. ${ }^{37}$ As one such appointee recalled,

'Kibaki chose his people carefully for the economic functions because of his background as an economist and Finance Minister ... He gave them a card to change and space to work ... You felt confident that you would be backed to make your own decisions and say no to people pressuring you'. ${ }^{38}$

Kibaki appointed Andrew Mullei as CBK governor in 2003. Mullei had risen through CBK's ranks to become research director by the late 1980s, then spent a decade with the IMF and Africa Centre for Monetary Studies. His appointment was greeted warmly by domestic and external actors alike, particularly by the IMF. However, Mullei's tenure would, as explained later, end abruptly in 2006, after he inadvertently overstepped his banking supervision brief. This saw the appointment of Njuguna Ndung'u, a 'world class econometrician', who would then see out Kibaki's presidency. ${ }^{39}$ Importantly, Ndung'u had, like Mullei, spent time with organisations that articulate a need to 'customise Western economics to the African context',

\footnotetext{
${ }^{37}$ Interview, former CBK manager, Nairobi, 21 March 2019.

${ }^{38}$ Interview, former CBK manager, Nairobi, 27 March 2019.

39 Interview, CBK manager, Nairobi, 29 April 2019.
} 
having been at the African Economic Research Consortium. ${ }^{40}$ This reflected Kibaki's preference for technocrats who were, like him, 'ultimate believer[s] in the market', but who were also sceptical of the 'shallow Western economics' pushed by the IMF and World Bank. ${ }^{41}$ This wariness towards donor orthodoxy was most acute with regards to monetary policy, but also played out in supervision, as the next sections reveal.

\subsection{Monetary policy}

Section 2 observed a slight regression - or, at least, greater variance - in monetary policy outcomes between 2002 and 2013. Inflation increased straightaway, from 2.2 percent in 2002 to 8.4 percent in 2004. This was followed by larger spikes in 2008 and 2011, of 15.1 percent and 14 percent, respectively. These levels, it should be stressed, were still manageable, and the inflationary pressures receded quickly. Nonetheless, one could perhaps still discern from these outcomes that there was a decline in CBK's performance during these years.

This would, however, be a superficial reading, as some of these pressures were related to factors outside of CBK's control. The inflation spike in 2008 was linked to the global financial crisis, which had a particularly severe effect on Kenya's open economy, as well as droughts across the East African region that exacerbated food prices (Nyorekwa and Odhiambo 2014). Kenya endured further droughts in 2011, in addition to oil price shocks, which again drove up prices (World Bank 2012).

Additionally, a focus on price stability alone seems too narrow a set of criteria by which to judge CBK's performance during these years, as informants claimed that Kibaki and his technocrats explicitly agreed to tolerate higher inflation, in order to achieve other policy goals which they felt were equally important. ${ }^{42}$ These claims are corroborated by a series of subtle changes to Kenya's monetary policy framework during Kibaki's presidency. In 2005, the Treasury, in consultation with CBK, dropped the 'below 5\%' inflation target that had been used since 1996, in favour of a more accommodating ' $5 \%$ with a tolerance of $+/-2 \%$ ' (Andrle et al. 2013:20). This was followed in 2007 with a change to the CBK Act, which stated that, in addition to promoting price stability, CBK was expected to contribute to the broader 'economic policy of the government, including its objectives for growth and employment' (quoted in Adam et al. 2010). In 2012, the leeway in CBK's formal inflation target was increased again, with the introduction of a $+/-2.5$ percent provision (CBK 2013).

As to what CBK's other monetary policy goals were, these can be found in NARC's Economic Recovery Strategy (ERS), which was released in 2003 to signal an end to the 'years of poor economic performance' under Moi, and to offer a developmental blueprint for the first years of Kibaki's presidency (Government of Kenya 2003:1). The ERC aimed for 'lending rates to decline significantly', as well as for a 'narrowing of interest rate spreads', the combination of which would 'enable private-sector credit to grow' and drive financial inclusion (ibid:4). Critically, the ERS sought to achieve this 'without putting undue pressure

\footnotetext{
${ }^{40}$ Interview, former CBK manager, Nairobi, 21 March 2019.

${ }^{41} \mathrm{lbid}$.

${ }^{42}$ Interview, economic analyst, Nairobi, 2 April 2019.
} 
on inflation', suggesting again that moderate inflationary pressures were accepted as an inevitability if CBK was going to be able to pursue these other objectives (ibid).

From the moment Kibaki entered office, CBK embarked upon a more expansive monetary stance. Through 2003 and 2004, it progressively lowered the cash reserve ratio from 10 percent to 8 percent then 6 percent (Bandiera et al. 2008). According to a then official, CBK also sought to boost the uptake of credit by the private sector by driving down Treasury Bill rates, which declined from over 10 percent in 2002 to between 1 and 3 percent during the first years of Kibaki's presidency. This outcome was described by World Bank analysts as 'exceptional' because even countries like 'Brazil and Turkey have had great difficulty in doing so [issuing local currency debt at single-digit rates] in spite of running significant primary surpluses far greater than Kenya's' (ibid:25). Trying to make sense of how this had been achieved, the analysts found some explanation in the fact CBK had worked with the Treasury and KRA to reduce Kenya's domestic borrowing requirements and to fund more of the budget through revenue mobilisation, as mandated within the ERS. Yet the report also hinted at CBK perhaps having kept the rates 'artificially low' through 'manipulation' (ibid:3). This was an accusation that one ex-CBK official claimed was made rather more forcibly by donors behind the scenes:

'The IMF said that we were practicing voodoo economics ... that we could not bring the rates down so quickly ... But that was the policy position. The president wanted interest rates to come down to levels that would allow private credit to grow and also grow our revenues. And that was also what the IMF wanted, to stop crowding out the private sector. It was just a different way of getting there ... We kept reassuring the IMF that it was just for a short time, to force banks who were sitting on piles of liquidity and growing fat on government borrowing to lend to the private sector and boost our revenues, but they did not listen. ${ }^{43}$

CBK's strategy was, however, broadly successful. Interest rate spreads declined from 13 percent in 2002 to 8 percent in 2005, then evened out at this more 'natural level' (Figure 9). ${ }^{44}$ This helped to drive average GDP per capita growth rates of 2.74 percent between 2002 and 2007, which represented Kenya's first five-year growth episode since 1972, when Kibaki was himself finance minister (Kimenyi et al. 2016). What is more, this was achieved with only moderate inflationary pressures in 2003-04. Thereafter, inflation quickly subsided, just as CBK had predicted. It was, according to one analyst, an example of what could be achieved when the organisations that comprise the macroeconomic technocracy were 'reading off the same page' and were willing to push back against donor orthodoxy. ${ }^{45}$

\footnotetext{
${ }^{43}$ Interview, former CBK manager, Nairobi, 27 March 2019.

${ }^{44} \mathrm{lbid}$

${ }^{45}$ Interview, former CBK director, Nairobi, 29 March 2019.
} 
Figure 9. Lending deposit spread, 2001-2013

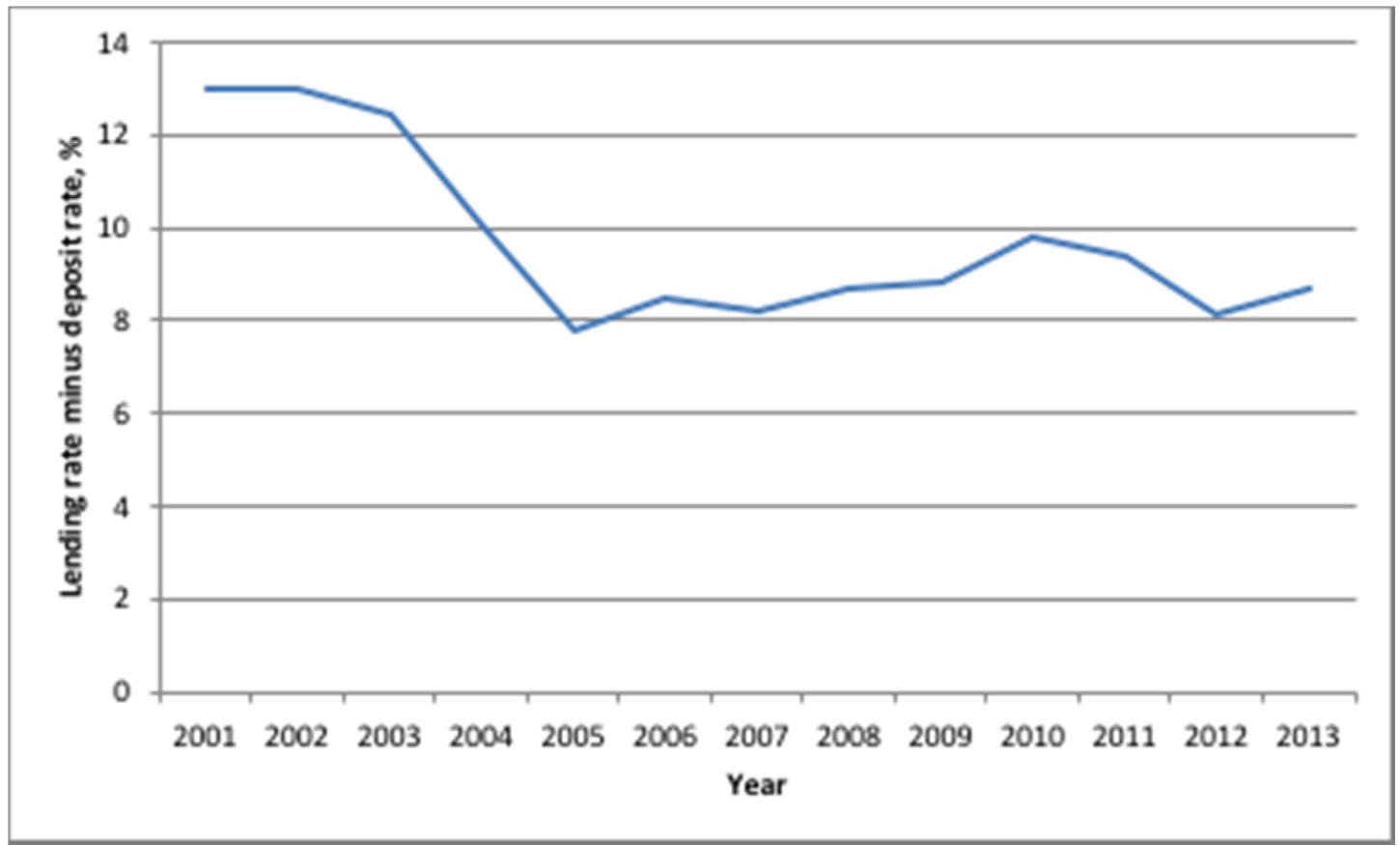

Source: WDI.

Another example of CBK challenging donor advice, and of its close cooperation with other macroeconomic institutions in doing so, came in its response to adverse economic conditions in 2008-09. As noted earlier, these were driven partly by the global financial crisis (GFC). However, in a sense, the GFC had only reinforced the pre-existing economic crisis that flowed from Kenya's 2007-08 election violence, which caused GDP per capita growth to plunge from an impressive 3.9 percent in 2007 to -2.5 percent in 2008. Reeling from these twin crises, Kibaki and his technocrats launched a counter-cyclical fiscal stimulus package in 2009 that was equivalent to 1 percent of Kenya's GDP, focused on social spending and rural infrastructure (Mwega 2010). CBK then backed this with an expansionary monetary stance that involved lowering its cash ratio from 6 percent to 4.5 percent and the Central Bank rate from 9 percent to 7 percent. This was, according to a CBK working paper which retrospectively analysed the intervention, 'one of the most historic shifts in the country's conduct of monetary policy ... in terms of both duration and the amounts of liquidity injected' (Were and Tiriongo 2012; Figure 10). It was also one that was initially discouraged by donors, who questioned the government's ability to implement such a large programme.

The intervention was, however, broadly successful - at least from CBK's side - as it led to an expansion in private-sector credit and a resumption of growth (ibid). ${ }^{46}$ This was even somewhat acknowledged by the World Bank (2011), albeit while it offered a caveat that

\footnotetext{
${ }^{46}$ Kasekende and Brownbridge (2010) have argued that Kenya's counter-cyclical stimulus, along with other sucu interventions in sub-Saharan Africa, was not fully successful, as lending rates - especially long-term rates - did not decline significantly, which restrained the uptake of credit by the private sector and led banks to accumulate reserves through government securities. However, Were and Tiriongo (2013:18) have argued that a significant proportion of the responsibility for this rests with the Treasury, as it struggled with actually implementing the stimulus and overcoming procurement-related delays. CBK, by contrast, is praised for its 'quick response' and 'flexibility' in carrying out the monetary policy side of the intervention.
} 
Figure 10. Net liquidity injections/withdrawals, 2008-2011

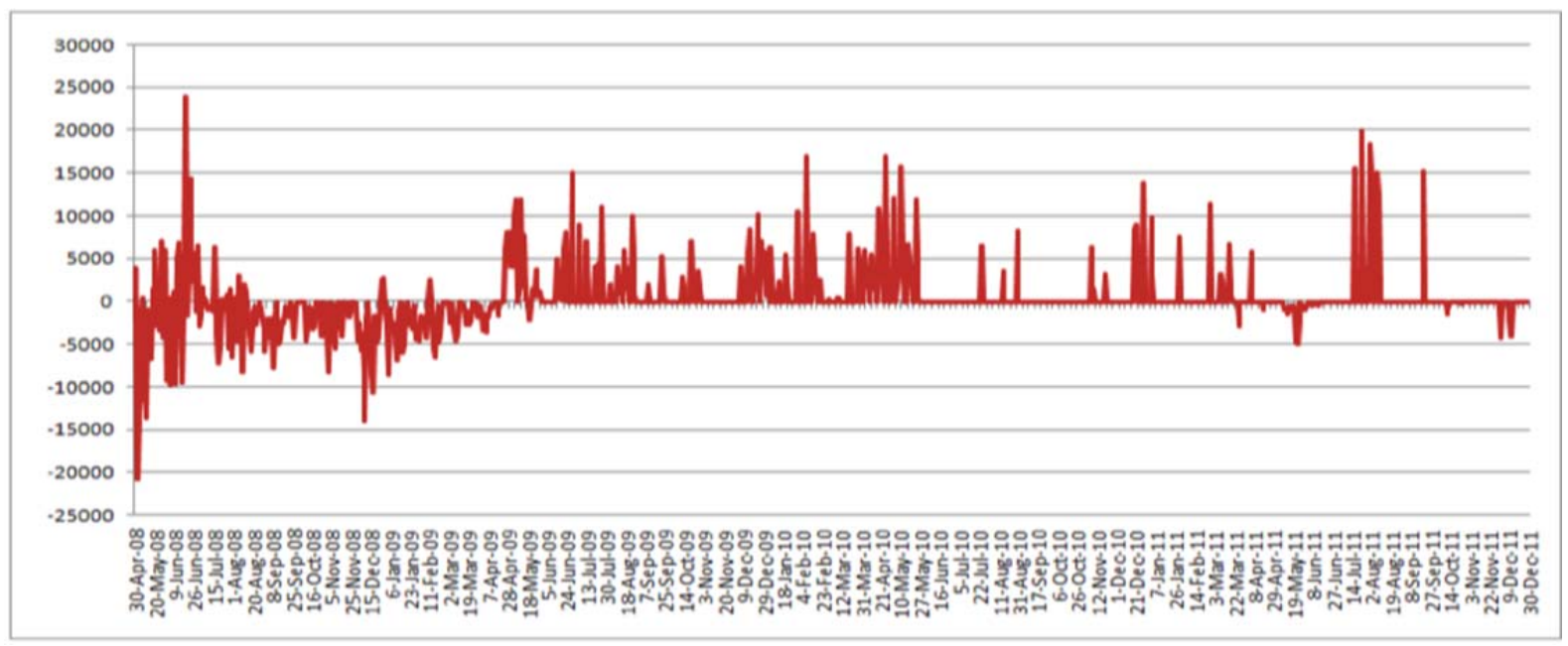

Source: Ibid.

CBK's expansionary stance had been retained for too long, causing inflation to surge again in 2011. However, CBK openly acknowledged this misstep, identifying the need for 'a clear exit strategy' as an 'important lesson' for the future (Were and Tiriongo 2012:21).

CBK's adaptive and contextually driven approach to monetary policy during this period was underpinned by various internal reforms. Having worked for the African Centre for Monetary Studies, which gave him a continent-wide perspective, Mullei felt that monetary policy needed to be 'opened up', a preference which was certainly in line with donor advice. ${ }^{47}$ These preferences also aligned with the sentiments of Kenya's ERS, which had called for a 'more transparent conduct of monetary policy' (Government of Kenya 2003:4). Mullei therefore created a monetary policy advisory committee in 2006, the last year of his tenure before being removed, which was then converted into a legally backed executive committee, the monetary policy committee (MPC), by Ndung'u in 2008. Demonstrating the president's interest in economic affairs, and his desire to keep on top of the slightest details within this domain, Kibaki took the time to approve all appointments, which were shortlisted jointly by the governor and finance minister. This resulted in 'purely technical' appointments, as well as a generally good balance between academics and practitioners. ${ }^{48}$

As PhD economists, Mullei and Ndung'u also appreciated the importance of a functioning research department. One source summarised the situation that Mullei had found when he entered office:

'The most important capacity within a Central Bank is to understand the policies that are needed. Otherwise you end up implementing policies that are generic and do not fit your own context because they are pushed from the outside ... [Mullei] came in and found that the research department was being asked to collect data that it did not know the purpose of ... The department was not working because staff did not

\footnotetext{
${ }^{47}$ Interview, CBK director, Nairobi, 6 April 2019.

48 Interview, CBK director, Nairobi, 28 March 2019.
} 
understand policy instruments and research was not feeding into decision-making ... It had been gutted.' 49

Mullei resuscitated the department, boosting its resources and staffing. These reforms were then continued by Ndung'u, who used IMF technical assistance to create a Monetary Policy Analysis Unit within CBK's research department in 2013 (IMF 2015). Utilising his skills as an econometrician, Ndung'u also worked with the unit to devise a 'dashboard' that offered upto-date analysis of economic performance 'ahead of that produced by the Treasury'. ${ }^{50}$ This was done by drawing on statistical data like electricity consumption, tourist arrivals, cement sales and mobile money transactions, all of which could be 'collected every week' and helped to inform the MPC's analytical capacities and decision-making, which had been overly reliant on the Treasury's quarterly updates. ${ }^{51}$

\subsection{Supervision}

Section 2 identified the 2003-2012 period as one of apparent high performance with regards to promoting financial stability. Kenya's FDI score improved consistently, save for a lull between 2008 and 2009, due largely to the GFC. NPLs also dropped dramatically, from 30 percent in 2002 to 5 percent in 2012. So, too, did these years witness marked improvements in the sector's capital adequacy and liquidity ratios, as well as profitability indicators. Finally, after 28 bank closures in the preceding years, there were only four between 2002 and 2013, all occurring within the first few years. From 2006, there were none.

Generally, informants agreed that this was a period of good performance, but also stressed that the picture was not quite as clear, or as positive, as it might first appear. Certainly, Governor Mullei was committed to developing CBK's supervisory capacities and, mirroring his efforts with monetary policy, to broadening out decision-making processes beyond a narrow clique. ${ }^{52}$ One source claimed that, when Mullei came in, he saw that the weakest area was supervision. It was literally driven by CEOs of banks, who wrote the reports and had them signed ... It was one of the least popular departments because staff were not allowed to do their jobs'. ${ }^{53}$ Mullei therefore decided to 'reshuffle the department'. ${ }^{54} \mathrm{He}$ 'brought in new blood' and 'worked with the Minister to move the old guard, who were influential, to other departments or even outside [the bank], because you could not just fire them'. ${ }^{55}$ With a new supervisory team, Mullei then enforced a stricter compliance regime, one pinned more clearly to Basel I and II principles, which were incorporated through new prudential guidelines. This resulted in a pronounced decline in NPLs between 2002 and 2006 - including within state-owned banks, which were restructured and had new managers appointed - as well as the managed closures of several small private banks (Arriola 2013; Upadhyaya 2020).

\footnotetext{
${ }^{49}$ Interview, former CBK manager, 27 March 2019.

${ }^{50}$ Interview, CBK director, Nairobi, 6 April 2019.

${ }^{51}$ Interview, former CBK manager, Nairobi, 18 April 2019.

${ }^{52}$ Interview, former CBK official, Nairobi, 2 April 2019.

${ }^{53}$ Interview, former CBK manager, Nairobi, 27 March 2019.

${ }^{54}$ Ibid.

$55 \mathrm{lbid}$
} 
However, an ex-CBK official recalled that these heightened regulatory efforts provoked resistance from banking cartels, who 'succeeded in bringing Mullei down in the end'. ${ }^{56}$ Here, the source is referring to the Charterhouse scandal, which not only brought about an end to Mullei's tenure, three years in, but to a backsliding in CBK's independence. There is a sense that Mullei almost gave too much autonomy to his supervisory department, as in 2006 it went after Charterhouse Bank, despite the fact that this 'bank' - which was really a 'pure money laundering operation' - was deeply embedded within Kenya's political establishment and had close links to various powerbrokers inside Kibaki's coalition. ${ }^{57}$ These reputedly included the attorney general, who, informants attested, acted on Charterhouse's bidding by persuading Kibaki that Mullei had violated legal procedures in closing Charterhouse and needed to be fired, even though the courts subsequently cleared him of all charges. ${ }^{58}$ Kibaki reputedly agreed to sack Mullei because Kenya was approaching another election in which the attorney general, from a swing region, was likely to be a key player. ${ }^{59}$ This episode reveals that there were still limits to the space afforded to technocrats by President Kibaki, who could not fully insulate them from the pressures of Kenya's virulent competitive clientelism.

Even more perniciously, the scandal ultimately undermined CBK's independence. This is because Kenya's MPs, many of whom had financial stakes in Charterhouse or similar 'banks', realised that the position of governor was too powerful and 'had to be tamed'. ${ }^{60}$ This resulted in draft legislation which advocated for a separation of powers between a governor responsible for macroeconomic policy and a chairperson responsible for organisational management (Ngigi 2013). The move was dressed up in the language of corporate governance, with reference to the 'best-practice' example of the Bank of England, which offers one of the few examples of such a structure in operation. However, informants insisted that this was also very much a 'political move' that was designed 'to prevent another Charterhouse'. ${ }^{61}$ The legislation was fiercely resisted by CBK, but encouraged by many banks, who lobbied MPs and various powerbrokers within Kibaki's government, reputedly including the attorney general. ${ }^{62}$ This ultimately saw the measure passed in 2012, to CBK's dismay.

Mullei's replacement, Ndung'u, proved more adept at reading the politics of his position as well as the confines within which CBK had to operate. This led him to ease the pace of reform that Mullei had instigated. Publicly, CBK continued implementing best-practice regulations, but behind the scenes offered 'latitude' to banks in meeting them. ${ }^{63}$ Particular beneficiaries of this 'look aside' approach were Equity Bank - which was owned by some of

\footnotetext{
56 Ibid.

57 Interview, former CBK manager, Nairobi, 3 April 2019; see also a report by the US embassy in Nairobi leaked by Wikileaks: https://wikileaks.org/wiki/A_US\$1.5_billion_Charter_House_of_horrors (accessed 18 November 2019).

58 Interview, former advisor to Kibaki, Nairobi, 3 December 2016.

59 Interview, journalist, Nairobi, 28 April 2019.

60 Interview, CBK director, Nairobi, 6 April 2019.

61 Interview, journalist, Nairobi, 28 April 2019. This claim is also echoed by a diplomatic cable from the US Embassy in Nairobi, published by https://wikileaks.org/plusd/cables/07NAIROBI2754 a.html (accessed 18 November 2019).

${ }^{62}$ Ibid; interview, CBK manager, Nairobi, 29 April /2019.

63 Interview, financial sector analyst, Nairobi, 12 November /2016.
} 
Kibaki's long-standing political financiers ${ }^{64}$ - as well as Safaricom, a telecommunications firm, which was allowed to encroach into traditional banking territory with its M-Pesa mobile money service in 2007, despite resistance from banks. Partly, CBK overrode this resistance to M-Pesa because Ndung'u and Kibaki wanted to promote financial inclusion, an objective that they certainly achieved by licensing it, particularly once Safaricom had expanded MPesa beyond a simple transfer service. However, it was also because shares in Safaricom, after two rounds of a politically compromised privatisation process, were held by elites from across the spectrum, who therefore had a stake in its success. ${ }^{65}$ Safaricom's ownership structure helps to explain the 'enabling regulation' which almost all scholars who have studied M-Pesa have identified as one of its key success factors (e.g. Porteous 2009; Mwega 2016).

Learning lessons from Mullei's downfall, Ndung'u also took a different approach to dealing with banks that flagrantly violated the rules. Ndung'u was a 'listening governor', who 'did not overreact' and 'put his energy into getting banks to improve behind-the-scenes'. ${ }^{66}$ This often involved 'call[ing] market players to discuss their issues over dinner', whereupon Ndung'u would 'encourage shareholders to quietly inject more capital'. ${ }^{67}$ Inevitably, being in such close quarters with banks made Ndung'u susceptible to their more corrupt overtures, and there are claims that he did occasionally succumb (Juma 2016). ${ }^{68}$ Informants also claimed that Ndungu, adopting a personalised approach akin to Cheserem, undermined the capacities of CBK's supervision department, as he tried to 'ensure that the licensing process went entirely through him'; this even led him to transfer the director of supervision to another department, because he was 'asking too many questions' ${ }^{69}$ Generally, however, informants echoed one source's broadly positive assessment of Ndung'u, which emphasised his embeddedness:

'Ndung'u had that extra feel for the industry because he made sure he got to know everyone. He trusted them, and they trusted him... People might say he was too cosy with the industry, but it worked. There was not a single bank failure under his watch and his understanding gave him the courage to try new things and experiment, which saw lots of innovation. ${ }^{70}$

\subsection{Overall performance}

CBK came to resemble a closer approximation of a POE during Kibaki's presidency, when the space for technocratic decision-making increased (albeit still with some limitations, as demonstrated by the Charterhouse saga). Moving on from Cheserem's tenure, there were important shifts in CBK's organisational culture, as emphasis was placed on building

\footnotetext{
${ }^{64}$ Interview, former Equity branch manager, Nairobi, 21 November 2016; interview, journalist, Nairobi, 28 April 2019.

${ }^{65}$ Interview, journalist, Nairobi, 5 May 2017; interview, former CBK official, Nairobi, 21 November 2016.

${ }_{66}^{6}$ Interview, former CBK manager, Nairobi, 21 March 2019.

${ }^{67}$ Interview, former CBK manager, Nairobi, 21 March 2019.

${ }^{68}$ Interview, journalist, Nairobi, 21 November 2016.

69 Ibid; see also https://wikileaks.org/plusd/cables/07NAIROBI2754 a.html (accessed 18 November 2019).

${ }^{70}$ Interview, banking executive, Nairobi, 13 March 2019.
} 
institutional capacities and broadening out decision-making processes, particularly with regards to monetary policy. Less progress was made with supervision, where political sensitivities restricted bureaucratic autonomy. Nonetheless, CBK performed strongly in its dual mandate, both in terms of monetary policy - where the internal capacities that it developed allowed technocrats to propose credible alternative interventions to those of donors - as well as in developing the financial sector, whose performance indicators converged on many middle-income countries (albeit not quite as impressively as the statistical data might suggest, given that banks could suppress key indicators like NPLs).

\section{Infringements, isolation and instability, 2013-present}

Informants pointed to a number of developments since 2013, both externally and internally to CBK, that have significantly affected its functioning. Externally, CBK has had to navigate a new institutional environment that was brought about by the unveiling of Kenya's new constitution in 2013, as well as by somewhat related changes to CBK's own constitution. The CBK Act was revised in 2012, partly to align it to Kenya's new constitution, especially requirements that top public-sector officials be appointed through competitive and transparent processes and that they also be vetted by parliament. However, as discussed earlier, the revised Act also included provisions about creating a position of chairperson, who was to assume management responsibilities from the previously all-powerful governor.

Aside from a new institutional framework, the year of 2013 also brought in a new ruling coalition, the Jubilee Alliance, whose leaders have proved unable - or unwilling - to insulate Kenya's macroeconomic technocracy from interfactional power struggles and rent-seeking in the way that Kibaki tried to do. Informants described Jubilee as essentially containing "two governments in one' - the first led by President Uhuru Kenyatta, the second by his deputy, William Ruto - and lamented that, far from ringfencing the macroeconomic technocracy, both have seen it as a key battleground for obtaining supremacy. ${ }^{71}$ These coalitional dynamics have reduced the scope for technocratic decision-making under Jubilee, in CBK and beyond, as the following sections will show.

Another implication of Jubilee's internal fragmentation is that CBK appointments have been increasingly influenced by factional considerations. During Jubilee's first two years, Njuguna Ndung'u continued as CBK's governor underneath an 'interim' chairperson, Mbui Wagacha, who was appointed from the existing board. However, by 2015, both had completed their tenures and were due for replacement. This saw the appointment of Patrick Njoroge as governor, who had seemingly secured his position by going through Kenya's newly competitive public sector recruitment process. Njoroge was a Yale-educated doctoral economist who had risen through senior positions at the IMF over a 20-year period, making him appear perfectly qualified. There were also perceptions that, as a member of the Catholic Church's Opus Dei, which shuns material possessions in favour of communal living, Njoroge had 'no political affiliations' or 'soft spots that could be exploited'. ${ }^{72}$ However, various sources - including from within CBK - claimed that Njoroge was always 'the president's man', as in addition to these qualities he was heavily backed by his former

\footnotetext{
${ }^{71}$ Interview, economic analyst, Nairobi, 2 April 2019.

72 Interview, financial services consultant, Nairobi, 8 December 2016.
} 
employers at the IMF and was, importantly, also a Kikuyu. ${ }^{73}$ This meant that Njoroge came from 'the right side of the ethnic divide' - helping to balance out Kalenjin leadership within the Treasury, as per Jubilee's power-sharing formula - but while also remaining palatable to non-Kikuyus because he was clearly not interested in such ethnic considerations himself. $^{74}$ The new, constitutionally enshrined public sector vetting process was described as little more than a 'rubber stamp'. ${ }^{75}$

As chairperson, Jubilee appointed Mohammed Nyaoga, who was seen by all Jubilee factions as a neutral candidate because he had been their lawyer in the post-2013 election litigations. This criterion seemingly took precedence over technical credentials, as 'President Kenyatta bypassed top economists and accomplished finance professionals' who had also applied (Omondi 2015). ${ }^{76}$ Even more concerningly, Jubilee's leaders struggled to agree on similar compromises for the rest of CBK's board, which for nearly two years consisted solely of Nyaoga, Njoroge and the Treasury's principal secretary. This meant that the board did not have the quorum that was mandated in the CBK Act, preventing it from officially meeting and deciding on organisational priorities and policies (Upadhyaya 2017). The implications that these institutional and coalitional dynamics had for CBK in conducting monetary policy and supervising the financial sector are explored below.

\subsection{Monetary policy}

Section 2 identified strong outcomes with regards to price stability, whereby inflation has constantly remained within a couple of percentage points of the 5 percent target. The only exception came in 2017, when Kenya held not one, but two, elections as the initial election or, at least, the presidential vote - was annulled by the Supreme Court. Inflation increased to 8 percent in 2017, from under 6 percent in 2016, but this was not in any way related to CBK printing money for the elections. Indeed, Njoroge refused calls to 'open the taps' from Jubilee's leaders, who have demonstrated neither the same respect for fiscal discipline as Kibaki, nor his determination to protect the macroeconomic technocracy from political pressures. ${ }^{77}$ Instead, the uptick resulted from the costs of holding two elections in a single year and a related slowdown in economic activity, as investors adopted a 'wait and see' attitude (World Bank 2018).

Generally, informants agreed that Njoroge is a 'very sharp macroeconomist', who has done a 'remarkable job' in keeping inflation so close to targeted levels. ${ }^{78}$ Njoroge has also followed his predecessors in enhancing the analytical capacities of CBK's research department and in strengthening its linkages with the monetary policy committee, of which the governor has effectively performed his role as chair. These efforts have allowed CBK to confront 'a difficult environment in which to conduct monetary policy'. ${ }^{79}$ For one, CBK has had to contend with the introduction, during Njoroge's first year in office, of interest rate

\footnotetext{
73 Interview, Central Bank official, Nairobi, 24 August 2016.

74 Interview, journalist, Nairobi, 5 May 2017.

75 Interview, journalist, Nairobi, 12 November 2016.

${ }^{76}$ Interview, journalist, Nairobi, 28 April 2019.

77 Interview, financial sector analyst, Nairobi, 3 November 2016.

78 Interview, journalist, Nairobi, 28 April 2019.

${ }^{79}$ Interview, financial sector analyst, Nairobi, 3 November 2016.
} 
caps. These quickly reduced the effectiveness of monetary policy, since any upward adjustment in CBK's benchmark rate to counter inflation automatically leads to 'politically undesirable' increases in interest rates that banks can charge (Safavian and Zia 2018). ${ }^{80}$ Njoroge opposed the caps, but was unable to prevent their introduction because Uhuru was already mindful of his re-election campaign in $2017 .^{81}$ The president realised that he would have had a hard time refuting opposition claims that he had been acting in his own commercial interests if he had not agreed to the caps, as his family owns a bank that was charging some of the highest rates. ${ }^{82}$ Importantly, the caps also had a powerful proponent within Jubilee, in the form of heavily overborrowed Deputy President Ruto, on whose support Uhuru was almost entirely reliant during his first term. ${ }^{83}$ This meant that Njoroge's protestations were always likely to come to nought. That said, informants felt that he could have made a more persuasive case by working closely with Treasury and commercial banks, both of whom also opposed the caps, to come up with alternative solutions, rather than 'shouting about it on his own'. ${ }^{84}$

CBK's ability to maintain low inflation has also been challenged by a growing context of fiscal dominance. The Treasury's borrowing appetite under Jubilee is the subject of another paper within this series, but the repercussions for CBK are that monetary policy has become increasingly 'reactionary', whereby 'the monetary tail is trying to wag the fiscal dog'. ${ }^{85}$ No longer are fiscal and monetary policies pulling in similar directions, as under Kibaki, because neither Uhuru nor Ruto have the understanding of - or, indeed, the interest in - economics to provide the coordinating presence that Kibaki did. ${ }^{86}$ Again, informants also highlighted how Governor Njoroge's somewhat 'bullish' approach has not helped here either, as his methods for trying to get the Treasury to change fiscal course have seemingly revolved around criticising its expansionary stance in public or going above the Treasury's head to the president, neither of which have helped to bring Treasury technocrats on board. ${ }^{87}$

The combined effects of the caps, coupled with the Treasury's growing borrowing appetite, has undermined the scope for interest rates to serve as a viable instrument of monetary policy, making exchange rate management important. ${ }^{88}$ In turn, the resort to these measures has caused friction between Njoroge and his former employers at the IMF, which has accused CBK of intervening in exchange markets to overvalue the shilling, despite Kenya's commitment to a floating regime (East African 2018). While this offers an interesting example of Njoroge not being entirely inflexible in his interpretation of the rules, as many would like to suggest, his actions should not be seen as an indication that he has fundamentally renounced his beliefs about the ideals of a floating exchange rate, but more

\footnotetext{
${ }^{80}$ Interview, banking executive, Nairobi, 2 November 2016.

${ }^{81}$ Interview, former CBK manager, Nairobi, 27 March 2019.

${ }^{82}$ Interview, Treasury manager, Nairobi, 12 November 2016.

${ }^{83}$ Interview, former CBK manager, Nairobi, 27 March 2019; interview, journalist, Nairobi, 28 April 2019.

${ }^{84}$ Interview, former CBK MPC member, Nairobi, 13 March 2019.

${ }^{85}$ Interview, economic analyst, Nairobi, 6 March 2019.

${ }^{86}$ Interview, former CBK manager, Nairobi, 18 April 2019.

${ }^{87}$ Interview, journalist, Nairobi, 28 April 2019.

${ }^{88} \mathrm{Ibid}$.
} 
that he sees such interventions as a last resort in averting 'economic crisis' ${ }^{89}$ This, one informant explained, is because many dollar-denomination foreign loans that have been taken on by the Treasury are now reaching a point of maturity, with the result that 'external payments will cripple the economy if the shilling devalues even slightly'. ${ }^{90}$ Njoroge, therefore, is seemingly 'buying time for the Treasury to clean up its debt management strategy', and for the interest rate caps to be lifted, before returning to a fully-floating currency. ${ }^{91}$

\subsection{Supervision}

Section 2 identified a possible trend of increased instability within the financial sector during this period. This is because it has not only witnessed declines across core financial soundness indicators, like capital adequacy, NPLs and returns on assets, but also a spurt of three bank closures after none in the preceding eight years. So, too, was there a drop in Kenya's FDI metric in 2015, for the first time in seven years.

Generally, informants echoed this picture of increased instability, albeit while stressing that the statistical data gives a somewhat misleading impression. They also linked this instability at least in part to changes in how CBK has tried to undertake its supervision mandate under its new leadership, and specifically to Governor Njoroge's inability - or, perhaps, his refusal - to adopt the more transactional and politically nuanced approach of his predecessors.

Shortly after entering office in June 2015 , Njoroge imposed a moratorium on bank licensing. He announced that - with 43 banks, more than in Nigeria or South Africa - the sector was overburdened and needed to be streamlined by weeding out the 'bad apples' (Aglionby 2015). Njoroge commenced his 'deep-cleaning' almost immediately, placing two banks Dubai and Imperial - into receivership within four months of his appointment, and following this up with a third - Chase - in early 2016 (ibid).

To be sure, these banks had serious governance issues. Imperial Bank, for example, had been 'running two sets of books' (Alushula 2019). ${ }^{92}$ In turn, these revelations raise questions about the tenure of Njoroge's predecessor, and the fact that one of Ndung'u's commonly identified successes is that there were no bank closures, since he allowed such banks to remain open. However, one analyst echoed others when he remarked that there are also 'legitimate questions about whether Njoroge exercised good judgement' in closing the three banks, especially in such short succession, as 'he could have brought down the whole system'. ${ }^{93}$ Njoroge, another informant agreed, 'did not perceive the risk properly because he had spent his life in an IMF environment and had never been a banker here ... He did not foresee the knock-on effects'. ${ }^{94}$

Even CBK reports have acknowledged that the rapid-fire closures caused 'liquidity stress', 'uncertainty in the market' and 'overall instability' (CBK 2017:9). This is because they led to

\footnotetext{
${ }^{89}$ Interview, economic analyst, Nairobi, 2 April 2019.

${ }^{90} \mathrm{lbid}$.

${ }^{91}$ Interview, journalist, Nairobi, 28 April 2019.

92 Interview, financial sector analyst, Nairobi, 12 November 2016.

${ }^{93}$ Interview, journalist, Nairobi, 5 May 2017.

${ }^{94}$ Interview, economic analyst, Nairobi, 6 March 2019.
} 
'panic withdrawal of deposits in small and medium banks' and the redirection of deposits to larger and more reputable banks, who themselves reduced their interbank lending to the smaller players (CBK 2016:32). This forced Njoroge to halt his programme of closures and support the affected banks through CBK's liquidity facilities, which included intraday lending, rediscounted government securities and an emergency 'lender of last resort' window. CBK (ibid) stressed that the 'situation [had] normalised' by the end of 2016, due to these interventions, but admitted that ' 12 banks' finished the year 'in violation of the Banking Act and CBK Prudential Guidelines, as compared to four in the previous year'. These violations were mainly related to 'non-compliance with liquidity ratios', due to 'deposit movement', as well as capital adequacy ratios, as smaller banks struggled making adequate provisions (ibid). Questioning CBK's claim that the situation had normalised by the end of 2016, the number of banks in violation actually rose to 15 in 2017 (CBK 2017).

The process of resolving the closures also became mired in slow-moving court cases and legal petitions launched by their shareholders. This was an entirely predictable outcome, according to one source, who said that 'in Kenya, everyone knows that as soon as you put a bank under receivership you open the process to all sorts of people who will try to take advantage'. ${ }^{95}$ This, the informant continued, was understood by Njoroge's predecessor, Ndung'u, under whom

'that fallout would not have happened, because he knew that you need to try every alternative [to closing a bank] until their last breath is gone. That is why he spent so much energy working behind the scenes, getting shareholders to inject more capital or convert shares to deposits. He knew that he needed to protect the industry, whereas Njoroge just seemed to wake up one morning and go in all-guns-blazing'. ${ }^{66}$

Perhaps more damaging than the instability that Njoroge caused within the financial sector was the effect that his actions had on CBK's independence and autonomy. Caught out by Njoroge's closures, the Treasury added amendments - which were roundly supported by MPs, many of whom have interests in banks - to the 2016 Finance Bill, which stipulated that CBK must consult with the Treasury before putting banks into receivership. This drew fire from the IMF for curtailing CBK's independence. ${ }^{97}$ It also led informants to suggest that Njoroge could have been more active in drawing lessons from the fallout that followed Mullei's attempt to close Charterhouse Bank, which triggered a similar negative feedback loop in terms of undermining CBK's autonomy and independence. ${ }^{98}$

Showing few signs of backing down, or of moderating his approach, Njoroge has continued to echo his initial declarations that 'forbearance is not in our vocabulary' (Aglionby 2015). CBK demands ' 100 percent compliance with regulations, no matter who your owners are'. ${ }^{99}$ The effects of this stringent regime can perhaps most clearly be observed in the spike in NPLs since 2015, which should not be interpreted as a sign that CBK is being less rigorous

\footnotetext{
95 Interview, banking executive, Nairobi, 13 March 2019.

${ }^{96}$ Ibid.

97 Interview, Treasury manager, Nairobi, 12 November 2016.

98 Interview, former CBK manager, Nairobi, 27 March 2019.

${ }^{99}$ Interview, banking executive, Nairobi, 21 November 2016.
} 
in its supervisory role, as might first appear. Instead, it demonstrates the exact opposite, as banks - including previously 'untouchable' banks like Equity - are facing more scrutiny in their reporting. ${ }^{100}$ Similarly, Njoroge has been oblivious to, or simply disinterested in, the political interests that underpin mobile money. In 2016, he sought to include mobile loans under the interest rate caps, which would have impinged upon the profits of powerful companies like Safaricom and President Kenyatta's own Commercial Bank of Africa. ${ }^{101}$ The governor reluctantly backed down, after being told in no uncertain terms that mobile loans whose rates effectively annualise at anything up to 120 percent, way above the 13 percent cap - were not to be included after all, but not before telling journalists that this was 'not being fair' (Wafula 2016). This statement did not go down well with Jubilee's leadership, given that Kenya was approaching an election where the opposition was criticising the costs of credit. Nor have they approved of Njoroge's generally more restrictive and cautious approach towards regulating mobile money, which owes to his preference for the ex-ante design of rules and regulations. ${ }^{102}$

\subsection{Overall performance}

CBK's performance has, similar to other periods, diverged across its mandated functions possibly to a greater extent than before. The period witnessed perhaps CBK's strongest performance with regards to price stability, given how consistently it has kept inflation within targeted levels. This is because monetary policy, as a function, plays to Njoroge's strengths, since it is relatively technical and procedural. Indeed, it is rumoured that Njoroge's status as a world-class macroeconomist with a reputation for conservatism was a key motivation for his appointment in the first place, as Jubilee needed to assure international capital markets of Kenya's macroeconomic fundamentals before it could embark on its grand borrowing plans. ${ }^{103}$

CBK has been somewhat less effective in ensuring financial stability, despite its heightened supervisory efforts. This is partly because Njoroge's inability to read the political headwinds, combined with his adherence to a rules-based and non-transactional approach, has led to heightened instability and a hobbling of CBK's independence. It has also led Njoroge into a barrage of law suits, parliamentary committee hearings and corruption investigations, as his efforts have 'made him a lot of enemies'. ${ }^{104}$ This has only further restrained CBK's operations, because Njoroge has had to spend an ever-increasing proportion of his time fighting off the people who are trying to force him out. Revealingly, many of these cases have been based on leaks and rumours originating from within CBK, where Njoroge has reputedly alienated many of his own staff. This is particularly the case within supervision, where staff feel like they were 'hung out to dry' by his public criticisms. ${ }^{105}$ However, dissatisfaction is to some extent organisation-wide, due to ongoing frustrations with

\footnotetext{
${ }^{100}$ Interview, financial services consultant, Nairobi, 8 December 2016.

101 Interview, financial sector analyst, Nairobi, 12 November 2016.

102 Interview, former CBK manager, Nairobi, 21 March 2019; interview, close confidante of President Kenyatta, Nairobi, 5 March 2019.

${ }^{103}$ Interview, economic analyst, Nairobi, 6March 2019.

104 Interview, financial sector analyst, Nairobi, 12 November 2016; interview, former CBK manager, Nairobi, 27 March 2019.

${ }^{105}$ Interview, former CBK official, Nairobi, 2 April 2019.
} 
Njoroge's micromanaging, his lack of trust and his efforts to clamp down on the (admittedly very generous) external training schemes that were offered by his predecessors. This has reduced staff motivation below CBK's top strata, dealing a blow to its organisational culture. ${ }^{106}$ There is also a sense that Njoroge has undermined CBK's broader embeddedness, as one ex-official remarked:

'Njoroge is clean, but he is closed. He does not engage with industry or his staff. He is not a manager or a builder. His style is remote. He only goes to academic events, not industry. You would never see him at a bank opening. He does not trust industry and industry does not trust him... He had no sense of how things worked when he came here. His understanding was purely theoretical... He has no sense of how to give and take, which is important for a position like that.' 107

\section{Analysis}

To enhance the coherency of the paper's analysis, this section is structured around two analytical tables. The first assesses the causal factors that have shaped CBK's monetary policy performance. The second does the same for financial sector supervision.

Table 1 shows that political settlement dynamics have shaped CBK's performance with regards to monetary policy. Kenya's shift to competitive clientelism actually initiated CBK's reform period, as the imperative of financing the 1992 elections led CBK to print money and orchestrate the Goldenberg scandal. This caused inflation to spiral out of control, prompting a backlash from politically influential domestic capitalist groups. Their lobbying for macroeconomic stability, combined with similar demands from donors, led CBK to implement a monetary policy framework that made price stability a priority over all other goals. Generally, this alignment of interests has remained in place ever since, explaining why CBK's performance in tackling inflation has remained strong, albeit with some fluctuations.

As one would predict, Kenya's political settlement creates pressures for CBK to 'open the taps' during elections. The paper identified this phenomenon during both the 1993-2002 and contemporary periods, under Presidents Moi and Kenyatta, respectively. However, the table shows that two factors helped to restrain these pressures, and more generally have kept CBK relatively insulated from the everyday realities of competitive clientelism. The first is the status of CBK itself, as it enjoys a de facto and de jure autonomy beyond any other Kenyan public sector organisation. Partly, this results from the legislative changes of the 1990s, but CBK's unique status also stems from the fact that governors have generally been adept at and understood the necessities of - balancing developmental and political goals, which has allowed them to carve out space and autonomy. Proving just how important this form of 'political management' has been (cf. Roll 2014:201), it is whenever CBK has been led by governors who have not understood the need for compromise and transactional dealmaking, such as under Mullei or Njoroge, that its independence and autonomy has been weakened. The second factor that has helped to restrain the dynamics of Kenya's political

${ }^{106}$ Ibid; iterview, former CBK manager, Nairobi, 21 March 2019.

107 Interview, former CBK manager, Nairobi, 26 March 2019. 
Table 1. Monetary policy

\begin{tabular}{|c|c|c|c|c|c|c|}
\hline Period & Indicators & Political settlement & $\begin{array}{l}\text { Leadership and } \\
\text { autonomy }\end{array}$ & $\begin{array}{l}\text { Organisational } \\
\text { culture }\end{array}$ & $\begin{array}{l}\text { Transnational } \\
\text { factors }\end{array}$ & Ideas \\
\hline $\begin{array}{l}1993- \\
2002\end{array}$ & $\begin{array}{l}\text { Declining } \\
\text { inflation, save } \\
\text { for } 1997 .\end{array}$ & $\begin{array}{l}\text { Shift to competitive } \\
\text { clientelism initiates } \\
\text { reform. Powerful } \\
\text { capitalists demand } \\
\text { stability. CBK } \\
\text { generally } \\
\text { successful, but } \\
\text { struggles during } \\
1997 \text { elections. }\end{array}$ & $\begin{array}{l}\text { Capable leadership. } \\
\text { Mix of political and } \\
\text { technical gives CBK } \\
\text { unprecedented } \\
\text { autonomy, allowing it } \\
\text { to resist pressure for } \\
\text { looser stance. }\end{array}$ & $\begin{array}{l}\text { Limited. Decision- } \\
\text { making not open. } \\
\text { Cheserem consults } \\
\text { handful of advisors } \\
\text { and undermines } \\
\text { research. }\end{array}$ & $\begin{array}{l}\text { Suspension of aid } \\
\text { and FDI freeze } \\
\text { helps initiate reform. }\end{array}$ & $\begin{array}{l}\text { CBK leaders } \\
\text { convinced by } \\
\text { neoliberal ideas, } \\
\text { esp. around price } \\
\text { stability. }\end{array}$ \\
\hline $\begin{array}{l}2003- \\
2012\end{array}$ & $\begin{array}{l}\text { Higher and more } \\
\text { variable } \\
\text { inflation. Spikes } \\
\text { in } 2004,2008, \\
2011 .\end{array}$ & $\begin{array}{l}\text { Political- } \\
\text { bureaucratic } \\
\text { coalition focused on } \\
\text { economic } \\
\text { governance. }\end{array}$ & $\begin{array}{l}\text { Mullei and Ndung'u } \\
\text { technically qualified } \\
\text { and networked to } \\
\text { Kibaki and Treasury, } \\
\text { enabling strong } \\
\text { coordination. }\end{array}$ & $\begin{array}{l}\text { Growing } \\
\text { organisational } \\
\text { capacities, e.g. } \\
\text { monetary policy } \\
\text { committee/research. }\end{array}$ & $\begin{array}{l}\text { Transnational } \\
\text { factors contribute to } \\
2008 \text { and } 2011 \\
\text { spikes. But } \\
\text { transnational actors } \\
\text { less influential, as } \\
\text { revenue mobilisation } \\
\text { dilutes budget } \\
\text { contributions. }\end{array}$ & $\begin{array}{l}\text { Coalition's ideas } \\
\text { (self-sufficiency, } \\
\text { fiscal } \\
\text { responsibility, } \\
\text { economic } \\
\text { heterodoxy) lead } \\
\text { CBK to resist } \\
\text { orthodoxy around } \\
\text { rigid inflation } \\
\text { targeting. }\end{array}$ \\
\hline & & & & & & \\
\hline
\end{tabular}




\begin{tabular}{|l|l|l|l|l|l|l|}
\hline 2013- & $\begin{array}{l}\text { Consistently low } \\
\text { inflation. }\end{array}$ & $\begin{array}{l}\text { Pressure to open } \\
\text { taps, but Njoroge } \\
\text { resists. Interest rate } \\
\text { caps passed to } \\
\text { stymie opposition } \\
\text { electoral campaign } \\
\text { on credit. }\end{array}$ & $\begin{array}{l}\text { Monetary policy } \\
\text { committee remains } \\
\text { highly autonomous, } \\
\text { even when CBK's } \\
\text { broader } \\
\text { independence is } \\
\text { reduced. }\end{array}$ & $\begin{array}{l}\text { In contrast to other } \\
\text { functions, Njoroge } \\
\text { does not micro- } \\
\text { manage. Plays role } \\
\text { of committee chair, } \\
\text { encouraging } \\
\text { alternative views. }\end{array}$ & $\begin{array}{l}\text { Preference of } \\
\text { international capital } \\
\text { markets and donors } \\
\text { for conservative } \\
\text { central bank } \\
\text { governor persuades } \\
\text { Jubilee to leave } \\
\text { Njoroge relatively } \\
\text { unhindered. }\end{array}$ \\
& & & & $\begin{array}{l}\text { Jubileas around } \\
\text { fiscal } \\
\text { responsibility } \\
\text { leading to fiscal } \\
\text { dominance. }\end{array}$ \\
\end{tabular}


Table 2. Financial sector stability

\begin{tabular}{|c|c|c|c|c|c|c|}
\hline Period & Indicators & Political settlement & $\begin{array}{l}\text { Leadership and } \\
\text { autonomy }\end{array}$ & $\begin{array}{l}\text { Organisational } \\
\text { culture }\end{array}$ & $\begin{array}{l}\text { Transnational } \\
\text { factors }\end{array}$ & Ideas \\
\hline $\begin{array}{l}1993- \\
2002\end{array}$ & $\begin{array}{l}\text { Varying } \\
\text { performance. } \\
\text { Improved } \\
\text { outcomes until } \\
\text { 1996, decline } \\
\text { thereafter. }\end{array}$ & $\begin{array}{l}\text { Necessity of } \\
\text { generating political } \\
\text { financing restrains } \\
\text { clean-up. Cheserem } \\
\text { performs difficult } \\
\text { juggling act. }\end{array}$ & $\begin{array}{l}\text { Less autonomy than } \\
\text { with monetary policy, } \\
\text { as certain banks } \\
\text { remain 'off-limits'. }\end{array}$ & $\begin{array}{l}\text { Cheserem reluctant } \\
\text { to delegate or build } \\
\text { capacities, given } \\
\text { political sensitivities. }\end{array}$ & $\begin{array}{l}\text { Donors offer } \\
\text { capacity-building } \\
\text { support, especially } \\
\text { after } 1997 \text { Asian } \\
\text { financial crisis. }\end{array}$ & $\begin{array}{l}\text { Pressure for CBK } \\
\text { to unveil best- } \\
\text { practice } \\
\text { legislation. But } \\
\text { mainly used to } \\
\text { signal credibility. }\end{array}$ \\
\hline $\begin{array}{l}2003- \\
2012\end{array}$ & $\begin{array}{l}\text { Improvement } \\
\text { across all } \\
\text { indicators. }\end{array}$ & $\begin{array}{l}\text { Kibaki protects } \\
\text { technocrats. But } \\
\text { Mullei's attempt to } \\
\text { close Charterhouse } \\
\text { before } 2007 \\
\text { elections leads to his } \\
\text { removal. }\end{array}$ & $\begin{array}{l}\text { Mullei's removal } \\
\text { convinces Ndung'u to } \\
\text { promote incremental } \\
\text { reform. Adopts more } \\
\text { transactional } \\
\text { approach, utilising his } \\
\text { embeddedness to } \\
\text { balance political and } \\
\text { developmental goals. }\end{array}$ & $\begin{array}{l}\text { Mullei reforms } \\
\text { supervision, but this } \\
\text { backfires when it } \\
\text { moves against } \\
\text { Charterhouse. } \\
\text { Ndung'u } \\
\text { (re)centralises } \\
\text { decision-making. }\end{array}$ & $\begin{array}{l}\text { Pressure to } \\
\text { implement Basel } \\
\text { and other best- } \\
\text { practice legislation, } \\
\text { which is expensive } \\
\text { and drains } \\
\text { resources, partly } \\
\text { explains why CBK } \\
\text { gives banks leeway. }\end{array}$ & $\begin{array}{l}\text { CBK rejects } \\
\text { 'shallow Western } \\
\text { economics', } \\
\text { which frowns on } \\
\text { monopolies, } \\
\text { giving Safaricom } \\
\text { space to launch } \\
\text { M-Pesa and } \\
\text { experiment, } \\
\text { driving financial } \\
\text { inclusion. }\end{array}$ \\
\hline
\end{tabular}




\begin{tabular}{|l|l|l|l|l|l|l|}
\hline 2013- & $\begin{array}{l}\text { Worsening } \\
\text { outcomes in } \\
\text { terms of NPLs, } \\
\text { capital } \\
\text { adequacy, } \\
\text { returns on } \\
\text { assets, closures } \\
\text { etc. }\end{array}$ & $\begin{array}{l}\text { Highly fragmented } \\
\text { Jubilee coalition } \\
\text { would present } \\
\text { difficulties for } \\
\text { anyone to try and } \\
\text { navigate politics. }\end{array}$ & $\begin{array}{l}\text { Njoroge undermines } \\
\text { CBK's independence } \\
\text { by trying to remain } \\
\text { free from politics. }\end{array}$ & $\begin{array}{l}\text { Njoroge alienates } \\
\text { many staff, by } \\
\text { micromanaging and } \\
\text { exposing them for } \\
\text { neglect of duties. }\end{array}$ & $\begin{array}{l}\text { External actors } \\
\text { support Njoroge's } \\
\text { rules-based regime, } \\
\text { backing him when } \\
\text { banks and politicians } \\
\text { try forcing him out. }\end{array}$ & $\begin{array}{l}\text { Njoroge } \\
\text { champions } \\
\text { international best } \\
\text { practice, due to } \\
\text { education and } \\
\text { IMF background. }\end{array}$ \\
\end{tabular}


settlement, meanwhile, is ideas. This was observed most clearly during Kibaki's presidency, when he tried to insulate the macroeconomic technocracy from the political pressures and power struggles that were undermining the wider bureaucracy, and resisted the temptation to pressure CBK, even during election periods, to adopt a looser stance. This created a kind of norm around not pressuring CBK that has, to some extent, restrained the ability of Kibaki's successors to do so.

Table 2 also identifies a causal role for the political settlement in creating a set of constraints within which CBK must operate when undertaking its financial sector mandate. This is because the overriding imperative of generating political financing within a context of competitive clientelism means that reforms to supervision must be incremental and transactional, given the extent to which Kenya's financial sector serves as a conduit for greasing patronage networks. Reforms must also be well timed, in the sense that attempting them during an election period is even more likely to provoke a backlash.

Proof of these reflections can be seen in the contrasting fortunes of Kenya's two recent CBK governors, as Ndung'u's politically savvy approach resulted in arguably Kenya's most sustained period of financial sector stability, albeit a somewhat superficial stability, given that he allowed banks with serious governance issues to continue operating. Additionally, Ndung'u's embeddedness with the private sector as well as the executive, in addition to his somewhat related willingness to experiment and take risks, helped to usher in a period of unparalleled innovation, driving the take-off of mobile money in particular. Governor Njoroge, by contrast, unleashed negative feedback loops with his premature attempts to enforce a rigid rules-based regime, causing instability within the financial sector and undermining CBK's independence. These findings generate broader reflections that successful Central Banks - and, indeed, POEs generally - will not necessarily be bastions of rulesbased governance, but are instead likely to represent more hybrid governance arrangements that combine legal-rational and patrimonial forms of rule. For Central Banks, certain functions, like monetary policy, are more technical and procedural, allowing a more rules-based approach. Others, like supervision, are more transactional and require political sensitivity.

\section{Central Banks and development}

The paper has also offered reflections on the role that Central Banks can play within a country's development process, particularly when they move beyond the narrow focus on inflation targeting that is encouraged by donors. Price stability is clearly important, having been identified as a key factor in the successes of the East Asian developmental states (Gore 2000). However, the impressive economic outcomes to which CBK contributed between 2002 and 2013, when it challenged the rigidities of donor orthodoxy, suggest that Central Banks should not be consumed with an overriding objective of keeping inflation at ultra-low levels, particularly the kind of 5 percent targets that Kenya and other African countries formally adhere to (Goldsbrough et al. 2007). President Kibaki and his technocrats agreed to tolerate 
slightly higher levels of inflation in exchange for being able to pursue other monetary policy goals that they deemed to be just as important. These included a decline in interest rate spreads and an expansion in private-sector credit, both of which CBK managed to achieve while generally keeping interest rates within double -figures, albeit with a misstep in 2011, when CBK retained its expansionary stance for too long. Importantly, however, CBK was open to acknowledging such mistakes and using them as reference points for the future. Overall, then, these reflections suggest that Central Banks should adopt an adaptive and contextually driven approach to monetary policy, one that is open to external advice and critique, but not unquestioning of it. Similar points have been made by officials from CBK's research department:

\begin{abstract}
'A strict rule-based approach to monetary policy, including inflation targeting, is not always desirable for the countries of sub-Saharan Africa ... Monetary policy should include sufficient scope for discretion ... No evidence exists to suggest that inflation targeting is the only framework that can achieve low and stable inflation ... without compromising other economic policy objectives' (Misati et al. 2012:146-147).
\end{abstract}

Such reflections also hold for the other side of CBK's mandate, namely financial sector supervision. Central Banks are often encouraged by donors to be riskadverse, with an emphasis on the ex-ante design of comprehensive legislative and regulatory frameworks. However, Kenya's success with mobile money actually suggests the opposite, as a key factor in M-Pesa's take-off was CBK's willingness to experiment and take risks under its highly embedded governor. Also vital was Ndung'u's cognisance of the political interests that could both underpin and resist the introduction of mobile money, as well as his ability to cut deals that helped to propel Kenya's mobile money revolution forwards, at a time when similar innovations were being stunted by vested interests in numerous other countries, from Mexico (Suárez 2016) to Nigeria (Lepoutre and Oguntoye 2018). Kibaki and his technocrats also shared a scepticism of the kinds of 'shallow Western economics which says that all monopolies are bad'. ${ }^{108}$ This motivated them to resist pressure to expose M-Pesa to premature competition, providing Safaricom with space to innovate with the platform and add new functions. Embedded within Kenya's wider financial ecosystem, M-Pesa users now access complex products spanning credit, savings, insurance and securities, explaining why the proportion of Kenya's population with access to formal financial services has surged beyond many middle-income countries. All of this was possible because of CBK's openness to experimentation and its learning-by-doing approach, and more broadly how this was backed by a president who wanted to drive financial inclusion.

\title{
9. Conclusion
}

This paper has identified the factors that have shaped CBK's performance throughout its post-reform era. Kenya's political settlement has played a significant

${ }^{108}$ Interview, former CBK manager, Nairobi, 21 March 2019. 
role, generating pressures for CBK on the monetary policy side, notably to loosen its stance during election periods, as well as in shaping financial sector supervision, by creating a set of tight political constraints within which CBK must navigate - or face having its independence curtailed. That said, the paper also found that CBK has, to some extent, been characterised by its relative insulation from Kenya's virulent competitive clientelism. It has, for example, enjoyed relatively stable leadership throughout the post-reform era, in contrast to the regular turnover that one observes in other Kenyan public sector organisations. Additionally, appointments to CBK's board, and particularly to its monetary policy committee, have been relatively technical and non-political, constrained less by the ethnic balancing considerations that shape the boards of other organisations. This, the paper argues, is because other factors have played a kind of countervailing role on the incentives generated by Kenya's political settlement. In particular, the paper pointed to the unprecedented autonomy that CBK enjoys, which derives from both formal and informal sources. The paper also identified a strong role for ideas, particularly during the presidency of Mwai Kibaki, when he tried to insulate CBK, and the wider macroeconomic technocracy, from political (and even donor) pressures. Transnational factors have also been significant, as external actors have offered more capacity-building support and oversight to $\mathrm{CBK}$ than any other Kenyan government organisation. More recently, the need for a competent Central Bank to serve as a signalling mechanism to the international community, and especially to global capital markets, has also moderated the pressure that ruling elites have exerted on $C B K$, particularly with regards to its monetary policy functions. 


\section{References}

Adam, C., Collier, P. and Ndung'u, N. (2010). Kenya: Policies for Prosperity. Oxford: Oxford University Press.

Aglionby, J. (2015). 'Kenya Central bank head seeks to weed out "bad apples". http://www.ft.com/cms/s/0/42135e78-9a84-11e5-be4fOabd1978acaa.htm|\#axzz3u1rQtTzJ (accessed: 26 June 2019).

Alushula, P. (2019). 'KCB locks in Sh5bn Imperial Bank assets in buyout bid'. https://www.businessdailyafrica.com/news/KCB-Sh5bn-Imperial-Bank/5395465237388-qs79ysz/index.html (accessed: 26 August 2019).

Andrle, M., Berg, A., Berkes, E., Morales, R., Portillo, R. and Vlček, J. (2013). 'Money targeting in a modern forecasting and policy analysis system: An application to Kenya'. Working Paper 13/239. Washington, DC: International Monetary Fund.

Arriola, L. (2013). Multiethnic Coalitions in Africa: Business Financing of Opposition Election Campaigns. Cambridge: Cambridge University Press.

Bandiera, L., Kumar, P. and Pinto, B. (2008). 'Kenya's quest for growth stabilization and reforms: But political stability?' Policy Research Paper. Washington, DC: World Bank.

Boone, C. (2005). 'State, capital, and the politics of banking reform in Sub-Saharan Africa'. Comparative Politics, 37(4): 401-420.

Brownbridge, M. and Harvey, C. (1998). Banking in Africa: The Impact of Financial Sector Reform since Independence. Oxford: James Currey.

CBK (1989). Annual Report. Nairobi: Central Bank of Kenya.

CBK (1998). Annual Report. Nairobi: Central Bank of Kenya.

CBK (2013). Annual Report. Nairobi: Central Bank of Kenya.

CBK (2016). Annual Bank Supervision Report. Nairobi: Central Bank of Kenya.

CBK. (2017). Annual Financial Sector Stability Report. Nairobi: Central Bank of Kenya.

Chege, M. (1994). 'The return of multiparty politics'. In J. Barkan (ed.), Beyond Capitalism vs. Socialism in Kenya and Tanzania. Boulder, CO: Lynne Rienner, pp. 47-74.

Cheserem, M. (2006). The Will to Succeed: An Autobiography. Nairobi: Jomo Kenyatta Foundation.

Dafe, F. (2019). 'The politics of finance: How capital sways African central banks'. The Journal of Development Studies, 55(2): 311-327.

East African (2018). 'Kenya criticises IMF over overvalued shilling remark'. https://www.theeastafrican.co.ke/business/Kenya-says-shilling-properlyvalued/2560-4873234-10nv12i/index.html (accessed: 26 June 2019).

Garriga, A. (2016). 'Central bank independence in the world: A new dataset. International Interactions, 42(5): 849-868.

Gichuki, J., Oduor, J. and Kosimbei, G. (2012). 'The choice of optimal monetary policy instrument for Kenya'. International Journal of Economics and Management Sciences, 1(9): 1-23.

Goldsbrough, D., Adovor, E. and Elberger, B. (2007). 'Inflation targets in IMFsupported programs'. Working Group on IMF Programs and Health 
Expenditures Background Paper. Washington, DC: Centre for Global Development.

Gore, C. (2000). 'The rise and fall of the Washington Consensus as a paradigm for developing countries'. World Development, 28(5): 789-804.

Government of Kenya (2003). Economic Recovery Strategy for Wealth and Employment Creation, 2003-2007. Nairobi: Ministry of Planning and National Development.

Grindle, M. (2012). Jobs for the Boys: Patronage and the State in Comparative Perspective. Cambridge, MA; Harvard University Press.

Hickey, S. (2019). 'The politics of state capacity and development in Africa: Reframing and researching "pockets of effectiveness"'. ESID Working Paper 177. Manchester: Effective States and Inclusive Development Research Centre, The University of Manchester.

Hickey, S., Sen, K. and Bukenya, B. (2015). The Politics of Inclusive Development: Interrogating the Evidence. Oxford: Oxford University Press.

IMF (2015). 'Evolving monetary policy frameworks in low-income and other developing countries - Background paper: Country experiences'. Washington, DC: International Monetary Fund.

Juma, V. (2016). 'Ex-CBK governor's wife sought favours from Imperial Bank boss'. https://www.businessdailyafrica.com/corporate/Ex-CBK-governor-s-wifesought-favours-from-Imperial-boss/539550-3088938-10h4jirz/index.html (accessed: 26 June 2019).

Kanyinga, K. (1994). 'Ethnicity, patronage and class in a local arena: High and low politics in Kiambu, Kenya, 1982-92'. In Gibbon, P. (ed.), The New Local Level Politics in East Africa: Studies on Uganda, Tanzania and Kenya. Uppsala: Nordiska Afrikainstitutet.

Kajwanja, P. (2009). 'Courting genocide: Populism, ethno-nationalism and the informalisation of violence in Kenya's 2008 post-election crisis'. Journal of Contemporary African Studies, 27(3): 365-387.

Kasekende, L. and Brownbridge, M. (2010). Post Crisis Monetary Policy Frameworks in Sub-Saharan Africa.Tunis: African Development Bank.

Khan, M. (2010). 'Political settlements and the governance of growth-enhancing institutions'. Mimeo. London: SOAS.

Killick, T. and Mewga, F. (1990). Monetary Policy in Kenya, 1967-88. London: Overseas Development Institute.

Kimenyi, M., Mwega, F. and Ndung'u, N. (2016). The African Lions: Kenya Country Case Study. Washington, DC: Brookings Institute.

Kinyua, J. (2001). Monetary Policy in Kenya: Evolution and Current Framework. Nairobi: Central Bank of Kenya.

Lepoutre, J. and Oguntoye, A. (2018). 'The (non-)emergence of mobile money systems in Sub-Saharan Africa: A comparative multilevel perspective of Kenya and Nigeria'. Technological Forecasting and Social Change, 131: 262275.

Misati, R., Nyamongo, E., Njoroge, L. and Kaminchia, S. (2012). 'Feasibility of inflation targeting in an emerging market: Evidence from Kenya'. Journal of Financial Economic Policy, 4(2): 146-159. 
Mwega, F. (2010). 'Kenya'. Global Financial Crisis Discussion Paper 17. London: Overseas Development Institute.

Mwega, F. (2016). 'Financial regulation in Kenya: Balancing inclusive growth with financial stability'. In Griffith-Jones, S. and Gottschalk, R. (eds.), Achieving Financial Stability and Growth in Africa. Oxford: Routledge.

Ndung'u, N. and Ngugi, R. (1999). 'Adjustment and liberalisation in Kenya: The financial and foreign exchange markets'. Journal of International Development, 11: 465-491.

Ngigi, G. (2013). 'CBK board taps new chairman to replace Ndung'u'. https://www.businessdailyafrica.com/markets/CBK-board-taps-new-chairmanto-replace-Ndung-u/539552-2012184-hc0rsyz/index.html (accessed: 26 June 2019).

Ngugi, R. and Kabubo, J. (1998). 'Financial sector reforms and interest rate liberalisation: The Kenya experience'. Research Paper 72. Nairobi: African Economic Research Consortium.

Nyong'o, A. (1989). 'State and society in Kenya: The disintegration of the nationalist coalitions and the rise of presidential authoritarianism 1963-1978'. African Affairs, 88(351): 229-251.

Nyorekwa, E. and Odhiambo, N. (2014). 'Monetary policy regimes and economic performance in Kenya'. Problems and Perspectives in Management, 12(4-2): 495-504.

O’Brien, F. and Ryan, T. (2001). 'Kenya'. In Aid and Reform in Africa: Lessons from Ten Case Studies. Washington, DC: World Bank.

ODI. (2014). East African Prospects: An Update on the Political Economy of Kenya, Rwanda, Tanzania and Uganda. Edited by Booth, D., Cooksey, B., GoloobaMutebi, F. and Kanyinga, K. London: Overseas Development Institute.

Omondi, G. (2015). 'Nyaoga's star rises as he is named CBK board chairman'. https://www.businessdailyafrica.com/economy/Nyaoga-s-star-rises-as-he-isnamed-CBK-board-chairman/3946234-2739000-v2r5yx/index.html (accessed: 25 October 2019).

Porteous, D. (2009). 'Mobilizing money through enabling regulation'. Innovations: Technology, Governance, Globalization, 4(1): 75-90.

Roll, M. (2014). The Politics of Public Sector Performance: Pockets of Effectiveness in Developing Countries. London: Routledge.

Rotich, F., Kathanje, M. and Maana, I. (2007). 'A monetary policy reaction function for Kenya'. Paper presented at 13th Annual African Econometric Society conference, Pretoria, 9-11 July.

Safavian, M. and Zia, B. (2018). 'The impact of interest rate caps on the financial sector: evidence from commercial banks in Kenya'. Working Paper 8393. Washington, DC: World Bank.

Suárez, S. (2016). 'Poor people's money: The politics of mobile money in Mexico and Kenya'. Telecommunications Policy, 40: 945-955.

Throup, D. and Hornsby, C. (1998). Multiparty Politics in Kenya: The Kenyatta and Moi States and the Triumph in the 1992 Election. London: James Currey. 
Upadhyaya, R. (2011). Analysing the Sources and Impact of Segmentation in the Banking Sector: A Case Study of Kenya. PhD thesis. London: School of Oriental and African Studies.

Upadhyaya, R. (2017). 'The political economy of Basel adoption in Kenya: A case of alignment of donor, government and banking interests'. Working Paper 131. Oxford: Global Economic Governance Programme.

Upadhyaya, R. (2020). 'Kenya: “Dubai” in the Savannah'. In E. Jones (ed.). The Political Economy of Bank Regulation in Developing Countries: Risk and Reputation. Oxford: Oxford University Press, pp. 218-239.

Wafula, P. (2016). 'Commercial Bank of Africa insists M-Shwari is not subject to new laws'. $\quad$ https://www.standardmedia.co.ke/business/article/2000217050/cbainsists-m-shwari-is-not-subject-to-new-laws (accessed: 31 October 2019).

Warutere, P. (2005). 'The Goldenberg conspiracy: The game of paper, gold, money and power'. Working Paper 117. Cape Town: Institute for Security Studies.

Were, M. and Tiriongo, S. (2012). Central Bank's Response to Economic Crises from a Developing African Economy Perspective: Lessons from Kenya's Experience. Nairobi: Central Bank of Kenya.

Were, M. and Tiriongo, S. (2013). 'Monetary policy response to economic crises from an African economy perspective: An examination of Kenya's experience'. International Journal of Economics and Research, 4(2): 13-29.

World Bank (1975). Kenya: Into the Second Decade. Washington, DC: World Bank:+

World Bank (2003). Bank Regulation and Supervision Survey. Washington, DC: World Bank.

World Bank (2011). The State of Kenya's Economy. Washington, DC: World Bank.

World Bank (2012). Kenya at Work: Energizing the Economy and Creating Jobs. Washington, DC World Bank.

World Bank (2018). Kenya Economic Update. In Search of Fiscal Space. Government Spending and Taxation: Who Benefits? Washington, DC: World Bank. 
